\title{
MECHANISMS IN ENDOCRINOLOGY Endogenous subclinical hypercortisolism and bone: a clinical review
}

\author{
I Chiodini ${ }^{1}$, C Eller Vainicher ${ }^{1}$, V Morelli ${ }^{1,2}$, S Palmieri ${ }^{1,2}$, E Cairoli ${ }^{1,2}$, A S Salcuni ${ }^{3}$, \\ M Copetti ${ }^{4}$ and A Scillitani ${ }^{5}$ \\ ${ }^{1}$ Unit of Endocrinology and Metabolic Diseases, Fondazione IRCCS Cà Granda-Ospedale Maggiore Policlinico, \\ Milan, Italy, ${ }^{2}$ Department of Clinical Sciences and Community Health, University of Milan, Milan, Italy, \\ ${ }^{3}$ Endocrine Unit, Department of Medical Sciences, University of Cagliari, Cagliari, Italy, ${ }^{4}$ Unit of Biostatistics, and \\ ${ }^{5}$ Unit of Endocrinology, "Casa Sollievo della Sofferenza", IRCCS, San Giovanni Rotondo, Foggia, Italy
}

\author{
Correspondence \\ should be addressed \\ to I Chiodini \\ Email \\ iacopo.chiodini@unimi.it
}

\begin{abstract}
In recent years, the condition of subclinical hypercortisolism $(\mathrm{SH})$ has become a topic of growing interest. This is due to the fact that $\mathrm{SH}$ prevalence is not negligible $(0.8-2 \%$ in the general population) and that, although asymptomatic, this subtle cortisol excess is not harmless, being associated with an increased risk of complications, in particular of osteoporosis and fragility fractures. As specific symptoms of hypercortisolism are absent in $\mathrm{SH}$, the $\mathrm{SH}$ diagnosis relies only on biochemical tests and it is a challenge for physicians. As a consequence, even the indications for the evaluation of bone involvement in SH patients are debatable and guidelines are not available. Finally, the relative importance of bone density, bone quality and glucocorticoid sensitivity in $\mathrm{SH}$ is a recent field of research. On the other hand, SH prevalence seems to be increased in osteoporotic patients, in whom a vertebral fracture may be the presenting symptom of an otherwise asymptomatic cortisol excess. Therefore, the issue of who and how to screen for $\mathrm{SH}$ among the osteoporotic patients is widely debated. The present review will summarize the available data regarding the bone turnover, bone mineral density, bone quality and risk of fracture in patients with endogenous $\mathrm{SH}$. In addition, the role of the individual glucocorticoid sensitivity in $\mathrm{SH}$-related bone damage and the problem of diagnosing and managing the bone consequences of $\mathrm{SH}$ will be reviewed. Finally, the issue of suspecting and screening for $\mathrm{SH}$ patients with apparent primary osteoporosis will be addressed.

\section{Introduction}

Subclinical hypercortisolism (SH) is a condition of cortisol excess in the absence of its classical signs and symptoms (i.e. striae rubrae, proximal myopathy, facial plethora, easy bruising) and it may be of both exogenous (i.e. iatrogenic) and endogenous origin $(1,2,3,4,5)$.

The possible skeletal damage due to the low oral dose of glucocorticoids (GCs, i.e. $<5 \mathrm{mg}$ /die prednisone equivalents) has been well known for many years $(6,7,8)$ and it is still a matter of concern even in patients taking GCs at substitutive doses for adrenal insufficiency $(8,9,10,11,12,13,14)$.
\end{abstract}

\section{Invited Author's profile}

Iacopo Chiodini is Head of the Service for the Diagnosis and Therapy of the Endocrine Diseases at Fondazione IRCCS Cà Granda - Ospedale Maggiore Policlinico in Milan and Professor at the Post-graduate School in Endocrinology and Metabolism, University of Milan (Italy). He is interested in the bone involvement in endocrine disorders, particularly in conditions such as primary hyperparathyroidism, diabetes mellitus and endogenous hypercortisolism.

() 2016 European Society of Endocrinology Printed in Great Britain
Published by Bioscientifica Ltd. 
The prevalence of the endogenous form of $\mathrm{SH}$ is probably higher than previously suspected $(3,15)$, considering that a subtle cortisol excess is estimated to be present in the $5-30 \%$ of patients bearing an incidentally discovered adrenal adenoma (adrenal incidentaloma, AI) $(16,17,18$, 19). As an adrenal incidentaloma is estimated to be present in up to the $4-7 \%$ of the adults $(20,21)$, the prevalence of SH may be between 0.2 and $2.0 \%(1,3)$. Less frequently, an endogenous $\mathrm{SH}$ is due to a slight adrenocorticotrophic hormone (ACTH) excess $(22,23)$. Given its high prevalence, the possible chronic consequences of $\mathrm{SH}$ are being deeply investigated. Besides hypertension and metabolic syndrome, this condition has been suggested to be detrimental for the skeletal health. Indeed, SH may lead to an increased risk of vertebral fractures, partially explained by a reduction in bone mineral density (BMD) and possibly associated with a decreased bone quality (24).

Several aspects of SH-related skeletal damage are currently debated. First, the role of dual X-ray absorptiometry (DXA) in predicting the risk of fractures is still unclear, as $\mathrm{SH}$ seems to impair bone microarchitecture rather than bone density $(25,26,27)$. Secondly, individual sensitivity to cortisol due to the different polymorphisms of the glucocorticoid receptor and to the different activity of 11beta-hydroxysteroid dehydrogenase enzymes may influence the skeletal effect of hypercortisolism (28, 29). Finally, endogenous SH may be more frequent than expected in osteoporotic patients (30), in whom the vertebral fractures may be the presenting symptoms of an otherwise asymptomatic cortisol excess (31).

The present review will summarize the available data regarding bone turnover, bone mineral density, bone quality and risk of fracture in patients with endogenous $\mathrm{SH}$. In addition, the role of individual glucocorticoid sensitivity in SH-related bone damage and the problem of diagnosing and managing the bone consequences of SH will be reviewed. Finally, the issue of suspecting and screening for SH patients with apparent primary osteoporosis will be addressed.

\section{Bone turnover, bone mineral density, risk of fracture and bone quality in patients with endogenous SH}

\section{Bone turnover}

Available studies regarding bone turnover, bone density, risk of fractures and bone quality in SH patients are summarized in Table 1. As far as bone turnover is concerned, several studies reported a reduction in bone formation as measured by osteocalcin in $\mathrm{SH}$ patients $(32,33,34,35,36,37)$. This finding is in keeping with the fact that glucorticoid excess inhibits osteoblastic differentiation and activity and increases osteoblastic apoptosis (38). However, other studies did not find a reduction in bone formation as evaluated by osteocalcin $(39,40,41)$ and/or bone alkaline phosphatase $(32,36)$. These discordances are likely due to the small sample size of the available studies, to the low reliability of the bone formation markers (42) and to the difference in the prevalence of eugonadal and hypogonadal patients and in the criteria used to define SH in the different studies. Moreover, it should be noted that, particularly in the condition of glucocorticoid excess, osteocalcin and alkaline phosphatase are not good markers of formation as they are directly regulated by glucocorticoids, and are, thus, disproportionately reduced by glucocorticoids. However, it is well known from clinical and experimental studies that glucocorticoids impair osteoblastic function, by either bone marker or histomorphometric studies (38), and, therefore, an impaired bone formation is likely to be present even in SH patients.

Data on bone resorption are more discordant, also depending on the marker assessed. The carboxyterminal telopeptide of type 1 collagen levels have been found to be enhanced $(32,37)$, normal $(34,40)$ or reduced (33), while the urinary deoxy-pyridinoline levels have been concordantly reported to be normal $(34,35,36$, 39, 40). Data regarding parathyroid hormone (PTH) levels in SH patients are scarce. Our data showed that AI female patients with SH had higher PTH levels than patients without SH $(34,35)$, and in one study, PTH levels were inversely correlated with femoral BMD (34). This association between femoral bone mass and PTH was also reported in studies by Hadjidakis et al. (41) and Osella et al. (32), although in both studies AI patients with SH the did not show an increase in PTH levels. Again, the small sample size of the studies and the difference between the criteria used for defining $\mathrm{SH}$ may explain the discordant data on bone resorption and PTH levels in SH. In addition, the increased bone resorption, which was found in some studies $(32,37)$, could even be due to the postmenopausal status of some patients included in the studies, as it is known that in the condition of estrogen deficiency, the skeletal tissue is more sensitive to the glucocorticoid excess (38).

In summary, in $\mathrm{SH}$, an uncoupling between bone apposition and resorption is present with the osteoblastic activity being predominantly affected, as happens in the overt form of hypercortisolism. 


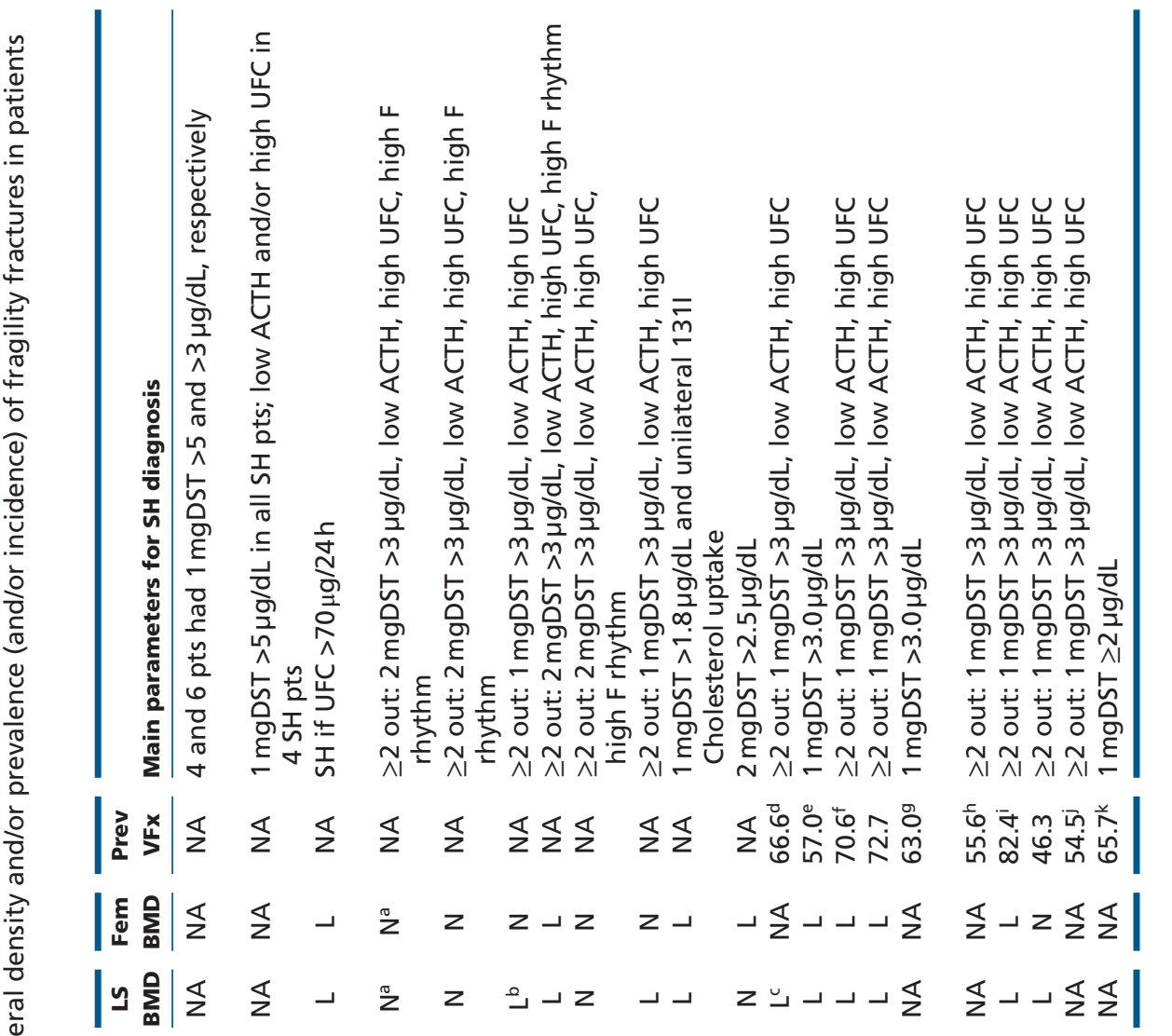

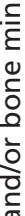

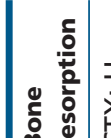

$z \quad z \quad z \quad z \quad z$

$z$

竞

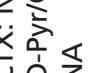

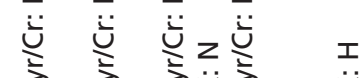

$\mid$

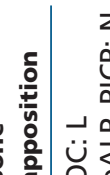

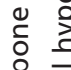

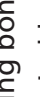

悹

哭

旁

$\frac{20}{\frac{0}{0}}$

$\frac{\frac{1}{0}}{\frac{\pi}{0}}$

$\stackrel{0}{+}$

范

1

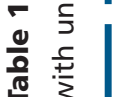

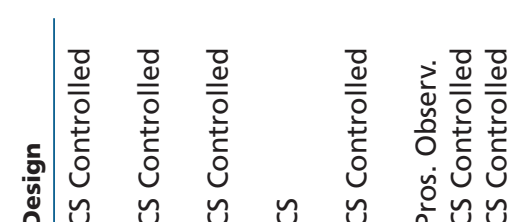

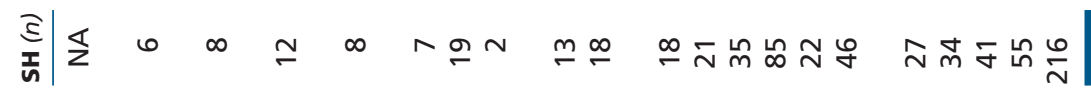

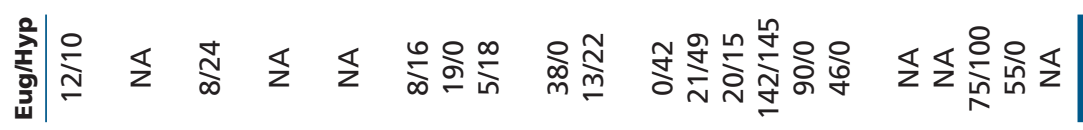

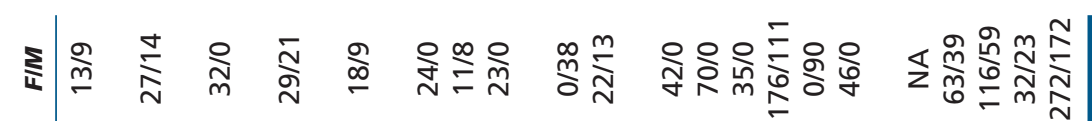

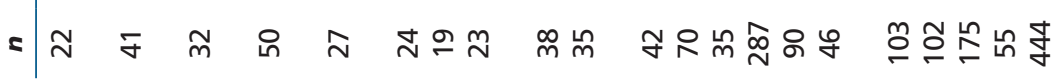

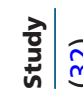

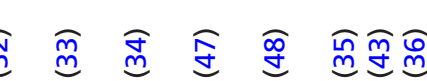

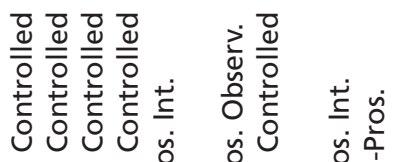

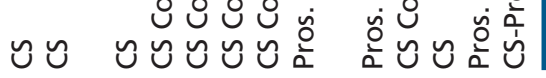

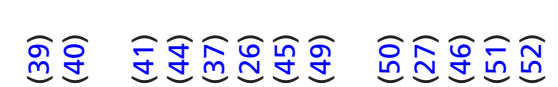

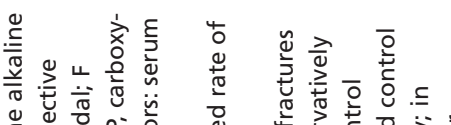

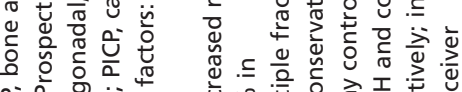

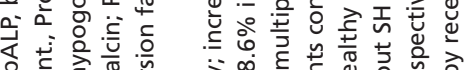

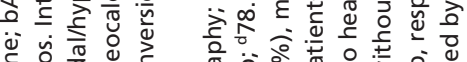

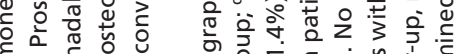

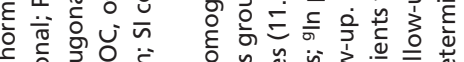

ट

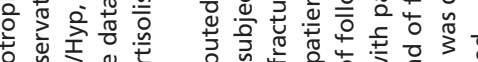

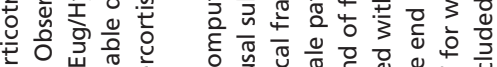

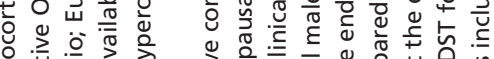

๘

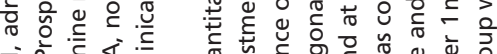

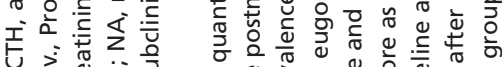

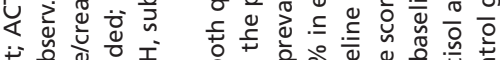

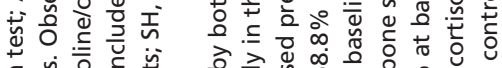

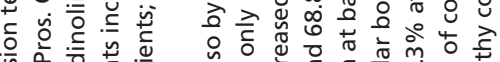

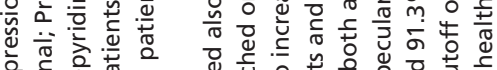

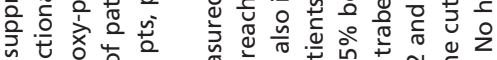

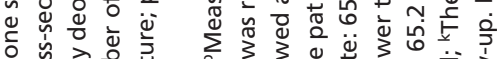

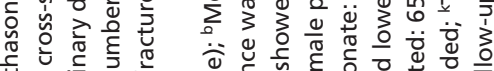

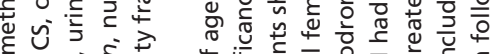

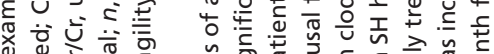

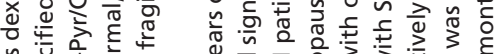

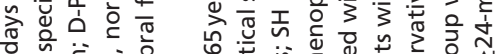
N

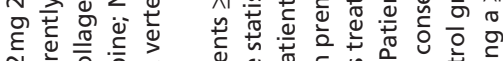

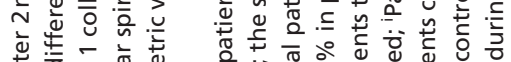

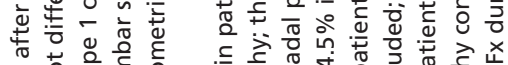
б

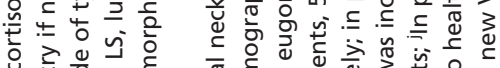

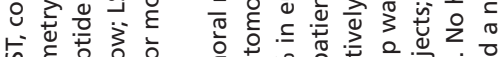

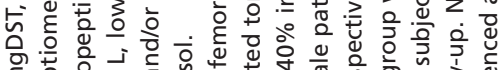

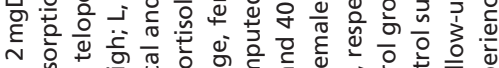

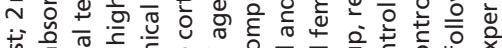

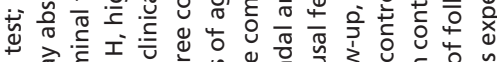

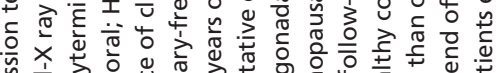

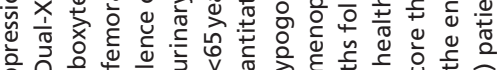

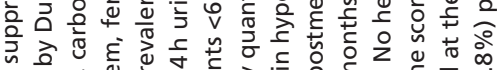

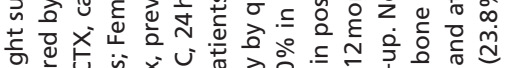

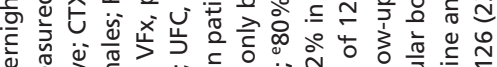
ठै

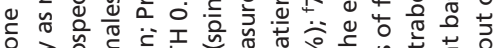

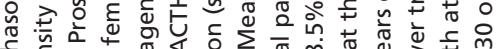

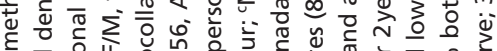
可 은

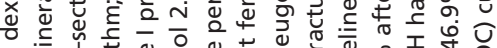

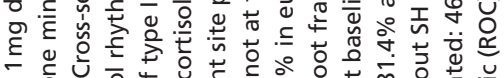

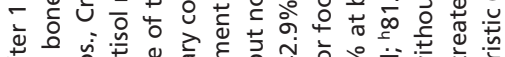

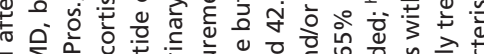

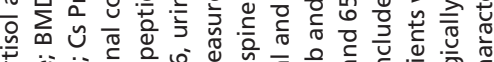

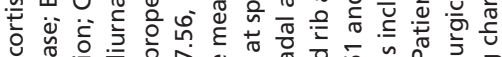

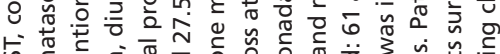

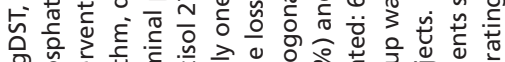

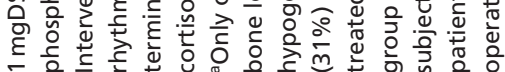




\section{Bone mineral density}

As expected on the basis of the known detrimental effect of cortisol excess on trabecular bone (38), most studies found a reduction in trabecular BMD measured at spine by DXA $(26,27,34,35,37,39,40,43,44,45,46,47)$ and/or quantitative computed tomography $(35,44)$ and by ultrasound at the proximal phalanges (43).

It must be observed that the studies that did not found a reduction in trabecular BMD in SH $(36,41,47,48)$ have important limitations. In the study by Rossi et al., BMD was measured only in patients <65years (47). In the study by Osella et al., the range of the $Z$-scores (numbers of SD from the mean BMD of the age- and sex-matched control subjects) in the control group was extremely large and, in fact, four out of five postmenopausal SH women had reduced BMD (48). Finally, in the study by Hadjidakis et al., a healthy control group was not included (41) and in the study by Francucci et al., only two SH patients were studied (36).

Therefore, given the amount of data showing a reduction in trabecular BMD in $\mathrm{AI}$ patients and the important pitfalls of all negative studies, in our opinion, the association between $\mathrm{SH}$ and the reduction in trabecular BMD should be considered well demonstrated.

On the contrary, data regarding cortical bone are more discordant. Indeed, several studies from our group and from other authors showed that in AI patients with $\mathrm{SH}$, the BMD at femur was reduced $(26,27,34,37,40$, $41,43,45)$. However, in other reports, a normal femoral BMD in SH patients was found $(35,39,46)$. It must be observed that in the largest available study (26) and in the studies enrolling only postmenopausal female patients or only eugonadal males, the femoral BMD was consistently found to be reduced $(34,37,42,45)$. Overall, even though the small sample size and the selection criteria of the population studied might have influenced the results obtained, it is conceivable that in $\mathrm{SH}$, as in overt cortisol excess (38), the cortical bone might be relatively preserved.

Studies assessing the change in BMD over time in $\mathrm{SH}$ patients are scarce and somewhat conflicting. While in a previous study an increased rate of bone loss was found in female patients with higher $24 \mathrm{~h}$ urinary free cortisol (UFC) levels (35), in two subsequent studies, the BMD did not vary over time in $\mathrm{SH}$ patients $(50,51)$. These apparently discordant findings are probably due to the different disease activity of the SH patients studied. Indeed, the mean UFC levels of SH patients in the former study were slightly higher (i.e. $75.7 \mu \mathrm{g} / 24 \mathrm{~h}, 209 \mathrm{nmol} / 24 \mathrm{~h}$ ) as compared with those of the subsequent studies (66.5 and $63.7 \mu \mathrm{g} / 24 \mathrm{~h}, 183$ and $176 \mathrm{nmol} / 24 \mathrm{~h}$ respectively).
In summary, $\mathrm{SH}$ probably affects trabecular bone at spine and possibly cortical bone at femur, and an increased bone loss over time may be appreciated particularly in patients with higher cortisol levels.

\section{Risk of fractures and bone quality}

At variance with data on bone turnover and $\mathrm{BMD}$, data regarding the risk of fracture are fully concordant and show that in $\mathrm{SH}$ patients, the prevalence of vertebral fractures varies between 46.3 and $82.4 \%$, and that it is higher than in control subjects $(26,27,35,44,45,46,49$, $50,51,52)$. In addition, the available longitudinal studies showed that $24-48 \%$ of $\mathrm{SH}$ patients may experience a new asymptomatic vertebral fracture over time $(50,51,52)$, while AI patients with SH, who underwent the surgical removal of the adrenal mass, had a strong reduction in the probability of a new vertebral fracture (51).

We conducted a random effects meta-analysis using the nine available studies assessing the prevalence of vertebral fracture in $\mathrm{SH}$. The estimated prevalence of vertebral fractures among $\mathrm{AI}$ patients with $\mathrm{SH}$ is $63.6 \%$ (95\% CI: $55.98-71.26 \%)$ in the presence of a certain grade of heterogeneity as suggested by the $Q$ test for heterogeneity $(19.09, P=0.014)$ and by the $I^{2}=58 \%$ (Fig. 1 ). The same analysis has been performed for assessing the prevalence of vertebral fractures in AI patients without $\mathrm{SH}$ (X studies, Fig. 2) and in the control populations when available (X studies, Fig. 3). These analyses suggest that the prevalence of vertebral fractures is increased even in patients apparently without SH (28\%, 95\% CI: 20-35\%) than in controls $(16 \%, 95 \%$ CI: 5-28\%, Cochran $Q$ test $Q=2.72, P=0.099)$. This is explained by the fact that some patients apparently without a clear biochemical picture of $\mathrm{SH}$ are, in fact, affected with a slight degree of hypercortisolism. Indeed, to date, the diagnosis of SH is still a challenge for clinicians, since, particularly in AI patients, cortisol secretion is highly fluctuant over time and is a continuum from completely normal to clearly increased levels. Therefore, the currently used parameters of cortisol secretion may be not enough sensitive for detecting a slight hypercortisolism in all affected individuals $(1,3)$.

The increased fracture risk in $\mathrm{SH}$ seems to be independent of gender and gonadal status. Indeed, in the largest cross-sectional study available so far, we found that even the premenopausal females and eugonadal males with $\mathrm{SH}$ have an increased prevalence of asymptomatic vertebral fractures (54.5 and 68.8\% respectively) as compared with healthy age- and gonadal status-matched control subjects (26). In keeping with 
this, in a subsequent longitudinal study, we demonstrated that in $\mathrm{SH}$ patients, the risk of a new vertebral fracture is 12 -fold increased regardless of age, gender, BMD and other possible confounders as compared with patients without SH (50). Apparently surprising, the degree of this risk in $\mathrm{SH}$ is similar to that reported in overt cortisol excess (24). However, SH is asymptomatic and, therefore, at the first diagnosis, the duration of the hypercortisolism in $\mathrm{SH}$ patients has been probably longer than that in patients with a clinically overt cortisol excess. In keeping with this, in the study by Tauchmanovà et al., the disease duration was found to be inversely correlated to BMD measured by finger ultrasound (43).

Interestingly, in $\mathrm{SH}$, the degree of $\mathrm{BMD}$ reduction is scarcely predictive of the fracture risk. This has been well demonstrated in several studies of our Group showing that the $40 \%$ of the eugonadal male AI subjects experienced a vertebral fracture in spite of a normal or only slightly reduced BMD (45) and that the presence of vertebral fracture at baseline and the occurrence of a new vertebral fracture during follow-up were independent of spinal BMD $(26,45,50)$ and of other possible confounders (i.e. age and gender).

The reduced reliability of BMD in predicting the fracture risk in SH suggests that, as in patients with overt cortisol excess (38) even in subjects with a subclinical form of hypercortisolism, a reduction in bone quality (i.e. bone microarchitecture), besides the decrease in bone density, is among the mechanisms underlying the increased fracture risk. However, bone quality can be assessed directly only by histomorphometric analysis of invasively obtained bone biopsy (53) or by microcomputed tomography systems (54). However, the idea of a reduced bone quality in $\mathrm{SH}$ was first suggested by two studies $(26,50)$ of our Group, evaluating in AI patients the spinal deformity index (SDI). The SDI is a semiquantitative method that integrates the number and the severity of vertebral fractures (55), which, in turn, have been suggested to be a surrogate index of bone microarchitecture (56). Therefore, the SDI may indirectly give information on bone quality. In the first study, we found that the SDI was higher in patients with SH than in those without $\mathrm{SH}$ and associated with the presence of SH regardless of age, body mass index, gender, spinal BMD and gonadal status (26). In the subsequent study, we demonstrated that the SDI worsened over time in AI patients with SH but not in those without SH (50).

More recently, the bone microarchitecture in AI patients has been indirectly studied using the trabecular bone score (TBS). This technique provides a gray-level texture measurement based on the use of experimental

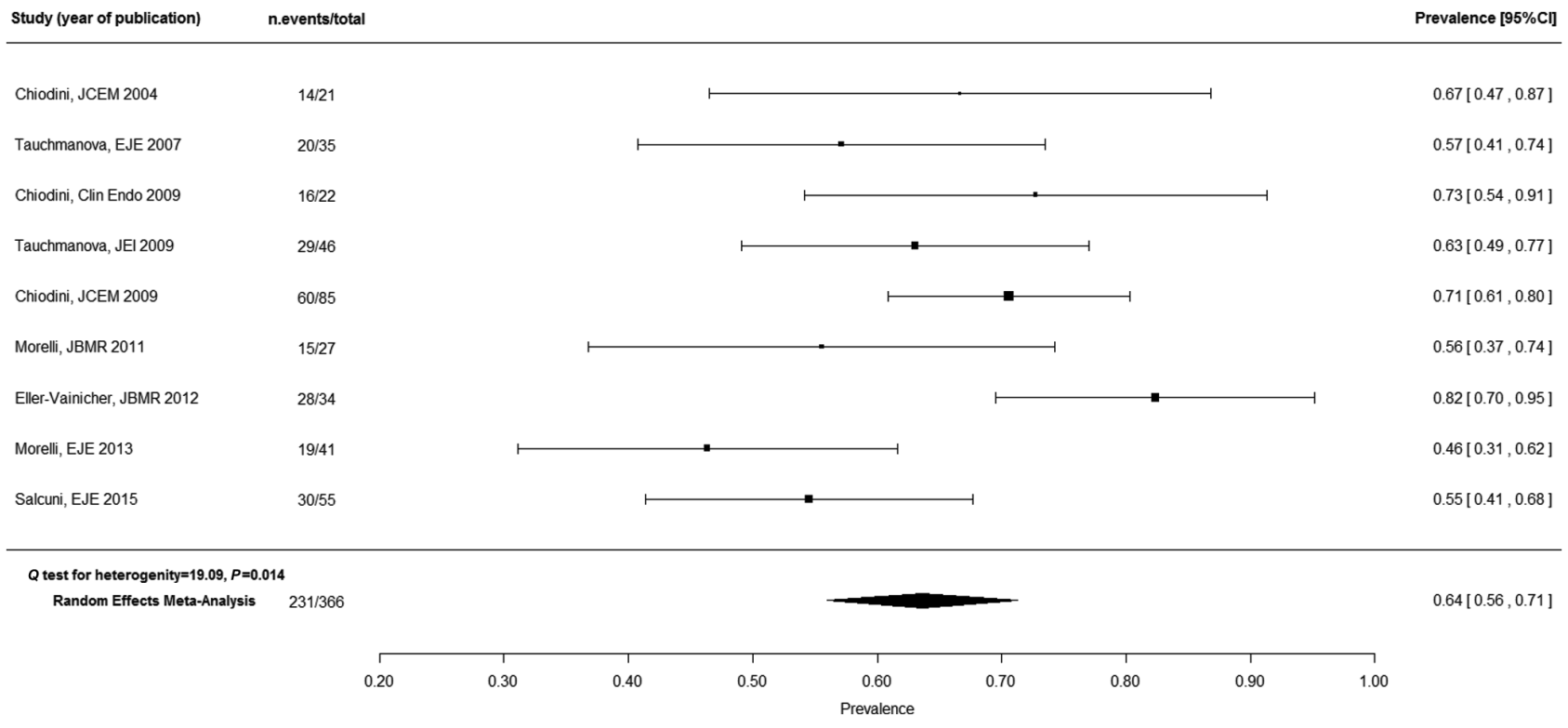

\section{Figure 1}

Random effects meta-analysis using the nine published studies assessing the prevalence of vertebral fracture in patients with adrenal incidentalomas and subclinical hypercortisolism. The estimated prevalence of vertebral fractures is $63.6 \%(95 \% \mathrm{Cl}$ : $55.98-71.26 \%)$ in the presence of a certain grade of heterogeneity as suggested by the $Q$ test for heterogeneity (19.1, $P=0.014)$ and by $I^{2}=58 \%$. 


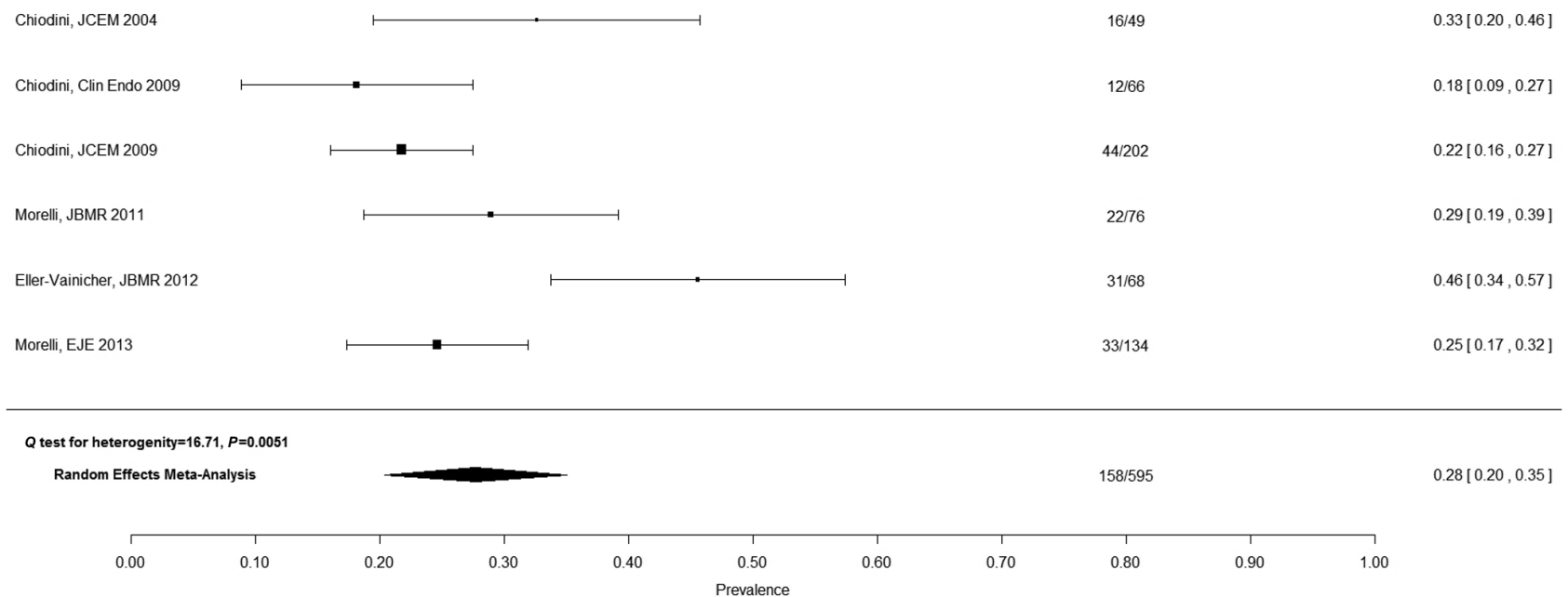

\section{Figure 2}

Random effects meta-analysis using the six published studies assessing the prevalence of vertebral fracture in patients with adrenal incidentalomas and without subclinical hypercortisolism. The estimated prevalence of vertebral fractures is $28 \%(95 \% \mathrm{Cl}$ : $20-35 \%)$ in the presence of a certain grade of heterogeneity as suggested by the $Q$ test for heterogeneity $(16.7, P=0.005)$.

variograms of two-dimensional (2D) projection images easily obtainable during a DXA scan (57), and it has been demonstrated to be strongly correlated with bone microarchitecture, regardless of BMD (58). In a study on 102 AI patients, we showed that TBS was reduced in AI patients with $\mathrm{SH}$ as compared with AI patients without $\mathrm{SH}$ and controls, and that it was correlated with the number and severity of vertebral fractures

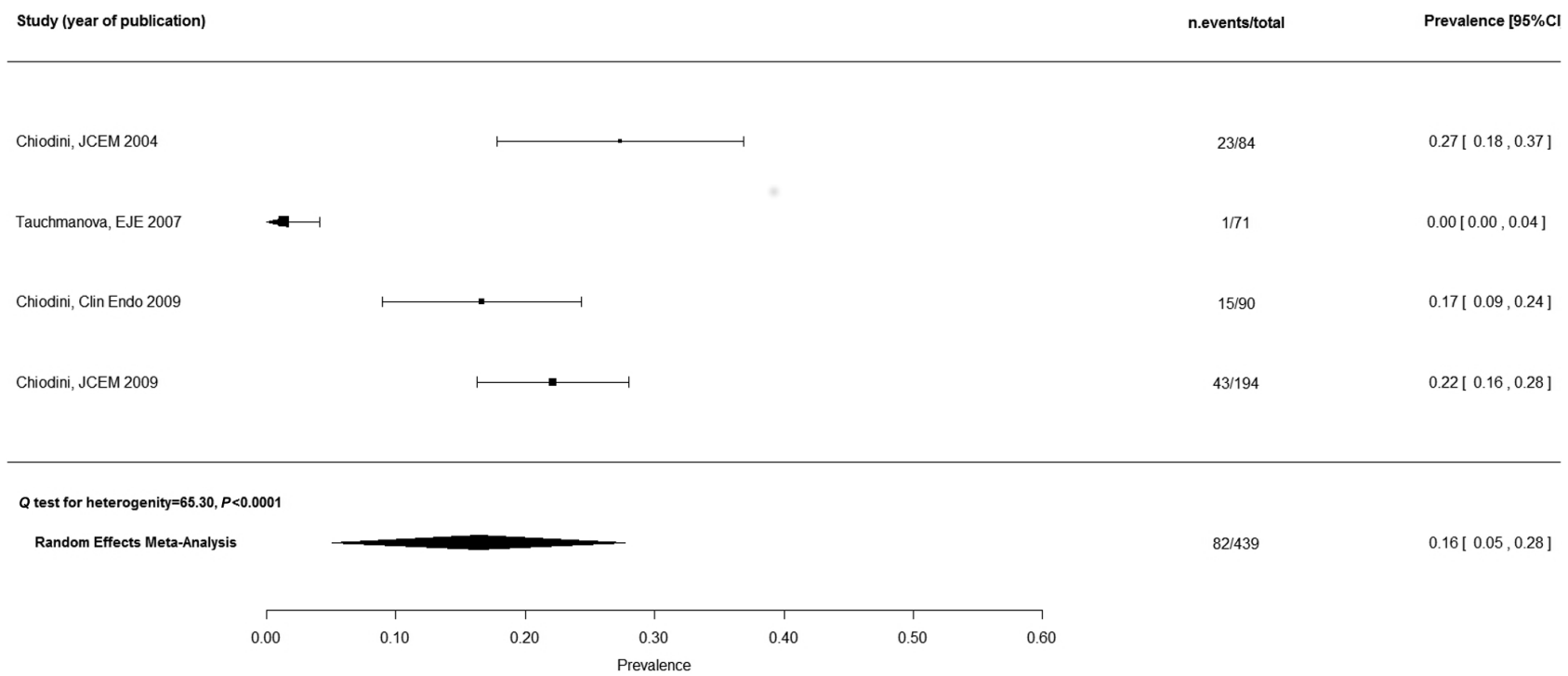

\section{Figure 3}

Random effects meta-analysis using the four published studies assessing the prevalence of vertebral fracture in the control subjects included in the studies assessing the prevalent vertebral fractures in patients with adrenal incidentalomas. The estimated prevalence of vertebral fractures is $16 \%(95 \% \mathrm{Cl}: 5-28 \%)$ in the presence of a certain grade of heterogeneity as suggested by the $Q$ test for heterogeneity $(65.3, P<0.0001)$. 
and associated with the presence of vertebral fractures and with the degree of cortisol excess, after adjustment for potential confounding factors (27). Finally, in a subgroup of patients followed for 24 months, TBS was associated with the occurrence of a new vertebral fracture regardless of spinal BMD and other potential confounders.

In summary, these data show that in $\mathrm{SH}$, the risk of vertebral fracture is increased regardless of age, gender, gonadal status and BMD and that it is probably associated with a reduction in bone microarchitecture at least as indirectly evaluated by SDI and TBS. In keeping with the data regarding other possible consequences of $\mathrm{SH}$, such as diabetes and hypertension (59), the recovery from $\mathrm{SH}$ seems to importantly reduce the vertebral fracture risk.

\section{Pathogenesis and role of the individual glucocorticoid sensitivity in SH-related bone damage}

The description of the cellular mechanisms underlying bone damage in hypercortisolism is beyond the scope of this review and it has been recently reviewed elsewhere (60). It is well known that the pharmacological GC administration is rapidly followed by a transient increase in osteoclast number and bone resorption and by an osteoblast inactivation and decreased bone formation, which lead to a rapid bone loss and increased risk of fracture. Subsequently, the bone resorption decreases and the persistent inhibition of osteoblastic activity remains the main cause of the loss of bone density and quality and of the persistent increase in fracture risk (60). Given the long disease duration in patients with the endogenous form of hypercortisolism, and in particular in those with $\mathrm{SH}$, the main mechanism underlying the skeletal damage is the reduction in the osteoblastic activity and of bone apposition, as indicated by the bone turnover data (Table 1). An important difference between the endogenous and the exogenous form of the glucocorticoid excess is that in the latter, the effect of the glucocorticoid administration on bone tissue may be influenced by the skeletal impact of disorders themselves (e.g. rheumatoid arthritis and systemic lupus erythematosus) for whom the glucocorticoids are given (61).

Besides its direct negative effect on the bone cells, the cortisol excess indirectly affects the skeleton by inhibiting the hypothalamic-pituitary-gonadal axis activity and the growth hormone (GH)-insulin-like growth factor I axis, as shown in patients affected with the clinically overt form of hypercortisolism $(62,63)$. It is unknown whether SH may lead to hypogonadotropic hypogonadism. At variance, some studies have evaluated the possible GH defect in SH patients $(64,65,66)$. Two studies apparently did not report an altered GH reserve in AI patients with SH $(64,65)$. However, in the former, the GH reserve was associated with the degree of cortisol secretion and the GH peak after GH-releasing hormone tended to be lower in patients with $\mathrm{SH}$ than in those without (64), and in the latter study, the four AI patients with ascertained $\mathrm{SH}$ showed a reduced GH reserve as compared with $\mathrm{AI}$ patients without $\mathrm{SH}$ (65). Finally, in a more recent study, we found that GH reserve was decreased in $\mathrm{SH}$ patients in relation to cortisol hypersecretion, and that the GH secretion increases after the recovery from $\mathrm{SH}$ (66).

Another possible contributor to the skeletal damage in patients with ACTH-independent cortisol excess may be the possible reduced adrenal dehydroepiandrosteronesulfate (DHEAS) secretion due to the blunted ACTH levels (67). Indeed, a correlation between DHEAS levels and BMD was described in patients with overt cortisol excess, accounting for a possible more severe bone involvement in patients with ACTH-independent hypercortisolism than in those with an ACTH-dependent form of cortisol excess, since in the latter patients, the DHEAS secretion is normal or even high, while in the former, it is usually blunted (68). In SH patients, the role of DHEAS in contributing to the bone loss has been scarcely investigated. However, the little data available is not consistent with a possible main effect of DHEAS on bone in the condition of SH (37) and, in keeping, even in patients with overt clinical hypercortisolism, the risk of vertebral fracture is independent of DHEAS levels $(69,70)$.

Recently, the issue of the role of the individual sensitivity to glucocorticoids in the skeletal tissue and in influencing the bone consequences of hypercortisolism has become a matter of debate. In Chinese (71) and in postmenopausal diabetic patients (72), the glucocorticoid receptor (GR) gene polymorphisms has been suggested to possibly play a role in osteoporosis. In the general population, the BclI and the N363S polymorphism of the GR have been associated with low $\operatorname{BMD}(73,74)$, while the ER22/23EK GR polymorphism is associated with a reduced sensitivity to glucocorticoids (75). In patients with clinically overt cortisol excess, the role of the different GR polymorphisms has been investigated, but the results obtained have been conflicting. In a previous study, patients carrying the 
BclI polymorphism of the GR showed reduced femoral BMD as compared with patients carrying the wild type GR (76), while in a subsequent study, the GR gene variants seemed not to play a role (77). It is likely that in the presence of high cortisol levels, as in most patients with clinically overt cortisol excess, the role of the GR polymorphisms-related glucocorticoid sensitivity may be limited. At variance, in the condition of a minimal cortisol excess, as in some individuals with diabetes (78), the GR polymorphism may influence the bone health.

Therefore, AI patients with and without SH might be an interesting model for studying the impact of the GR polymorphism in modulating the skeletal sensitivity to the glucocorticoid excess. However, in AI patients, the few available data on this issue are not conclusive. In a previous study, we found that in AI patients, the contemporary presence of homozygous BclI and heterozygous N363S GR polymorphism was associated with fragility vertebral fracture (28). However, in a further study, the association between the GR polymorphism and the BMD in AI patients was absent, but the possible differences in the presence of vertebral fractures were not assessed (79). It is possible to hypothesize that in these studies, the small sample size could have influenced the results.

The other possible main determinant of the individual bone sensitivity to glucocorticoids is the 11beta-hydroxysteroid dehydrogenase type 1 (11ßHSD1) activity, which seems to be important for the bone health in the conditions of both normal and increased cortisol levels $(80,81)$. Indeed, in vitro studies showed that the inhibition of $11 \beta \mathrm{HSD} 1$ improves osteoblast differentiation (82) and that it protects osteoblasts against the glucocorticoid-induced dysfunction (83). In keeping with these data, the polymorphic variants of the $11 \beta \mathrm{HSD} 1$ gene have been shown to be associated with $\operatorname{BMD}(84,85)$ and fracture risk (86) in postmenopausal osteoporotic women without clinically apparent hypercortisolemia. The role of the $11 \beta \mathrm{HSD} 1$ in patients with cortisol excess has been scarcely investigated. Szappanos et al. showed that the 83,557 insA variant of the gene coding 11ßHSD1 was associated with serum osteocalcin levels in patients with clinically overt glucocorticoid excess (87). A recent study showed that in AI patients, 11ßHSD1 activity was not associated with the possible SH complications such as diabetes and hypertension (88), but its influence on $\mathrm{BMD}$ and on the fracture risk in patients with $\mathrm{SH}$ has never been studied.

\section{Management of the possible bone consequences in patients with $\mathrm{SH}$}

\section{Diagnosis}

The first challenge in evaluating the possible bone consequences of $\mathrm{SH}$ is related to the fact that the presence of SH itself is often difficult to ascertain. The revision of the studies investigating the biochemical diagnosis of SH is beyond the aim of the present review and it has been recently published elsewhere $(3,4,5,59,89)$. Looking at Table 1, all studies addressing the topic of the bone involvement in $\mathrm{SH}$ were performed on AI patients making an a priori classification in subjects with or without SH. Most studies used the presence of at least two altered parameters among the unsuppressed cortisol levels (i.e. $>1.8 \mu \mathrm{g} / \mathrm{dL}, 50 \mathrm{nmol} / \mathrm{L}$, or $3.0 \mu \mathrm{g} / \mathrm{dL}, 83 \mathrm{nmol} / \mathrm{L}$, or $5.0 \mu \mathrm{g} / \mathrm{dL}, 138 \mathrm{nmol} / \mathrm{L}$ ) after $1 \mathrm{mg}$ dexamethasone overnight suppression test (1 mgDST), increased UFC levels or reduced $(<10 \mathrm{pg} / \mathrm{dL}$ or $<5 \mathrm{pg} / \mathrm{dL},<2.2 \mathrm{pmol} / \mathrm{L}$ or $<1.1 \mathrm{pmol} / \mathrm{L}$ ) ACTH levels. However, these criteria for diagnosing $\mathrm{SH}$ are probably not enough sensitive as suggested by the finding that in several studies, the AI patients without $\mathrm{SH}$, who have been surgically treated for the tumor size or growth, experienced the amelioration of some metabolic consequences of $\mathrm{SH}(47,90,91,92)$. In keeping, as compared with premenopausal healthy control subjects, the premenopausal AI patients without SH showed an increased prevalence of vertebral fragility fractures (49) and a reduced TBS (27). Because to date the diagnosis of $\mathrm{SH}$ is defined using arbitrary cutoffs of indexes of cortisol secretion, it is possible to hypothesize that some patients classified as not having SH might have, in fact, a mild degree of cortisol hypersecretion.

In a study aimed to assess the diagnostic accuracy of cortisol levels after 1mgDST for predicting the risk of vertebral fracture in AI patients, we showed that the confirmed cortisol level after $1 \mathrm{mgDST} \geq 2 \mu \mathrm{g} / \mathrm{dL}$ $(55 \mathrm{nmol} / \mathrm{L})$, in the absence of possible interfering medications and/or diseases, was the best parameters for identifying patients at risk for fractures with a $80 \%$ sensitivity and a $68.8 \%$ specificity (52).

The X-ray at spine should be repeated after 18 and 36 months since the first evaluation. In the absence of new vertebral fracture during a 36 months follow-up, a further X-ray evaluation is not useful. Otherwise, it would increase the cancer risk and it is not justified by the available literature evidences. Unfortunately, no data are available regarding the possible use of vertebral morphometry by DXA in SH patients. 
The second difficulty in diagnosing the possible consequences of $\mathrm{SH}$ is related to the reduced reliability of the BMD measurement in identifying the $\mathrm{SH}$ patients at risk for fractures. Indeed, although in $\mathrm{SH}$ patients the spinal BMD is associated with the prevalent and incident vertebral fracture (3), it is probably not enough sensitive for detecting individuals with asymptomatic vertebral fracture and the fracture risk is independent of the BMD reduction (50). In this field, the determination of TBS might be of some help. A study on more than 100 AI patients with and without SH found that a TBS Z-score $\leq 1.500$ and a spinal BMD $Z$-score $<0.00$ showed a $79 \%$ specificity (sensitivity $50.8 \%$ ) for predicting fractures, whereas a TBS $Z$-score $>1.5$ plus a spinal BMD $Z$-score $\geq 0.0$ had a $88.1 \%$ specificity (sensitivity $37.2 \%$ ) for excluding fractures (27).

Overall, these data suggest that all AI patients with cortisol levels after $1 \mathrm{mgDST} \geq 2 \mu \mathrm{g} / \mathrm{dL}(55 \mathrm{nmol} / \mathrm{L})$ should undergo the determination of BMD by DXA and the assessment of the presence of vertebral fractures by vertebral morphometry (Fig. 4). In addition, since in $\mathrm{SH}$ the fracture risk is increased regardless of the BMD reduction, all AI patients with possible or ascertained $\mathrm{SH}$ should be screened for the occurrence of new vertebral fractures during the follow-up. It is important to underline that the information regarding the bone status in SH patients may change the overall therapeutic approach in the individual AI patient with not yet established SH. Indeed, in AI patients with possible $\mathrm{SH}$, the usefulness of surgery is debatable. However, if some possible SH consequences are present, the surgical approach has more probabilities to be successful (93).

\section{Therapy}

Currently, only one study has been published on the effect on bone of the surgical treatment of AI patients with SH. In this study, on 55 patients with and without $\mathrm{SH}$ longitudinally followed for more than 24 months, surgery was associated with a 30\% reduction in the fracture risk regardless of age, gender, follow-up duration, cortisol after $1 \mathrm{mgDST}$ levels, spinal BMD and presence of vertebral fracture at baseline (51). Though not randomized, in this study, the baseline characteristics of surgically treated and conservatively managed subjects were comparable. Therefore, on the basis of available data, surgery has to be considered in SH patients at risk for fracture.

The only study evaluating the effect of a bone-active drug on the risk of vertebral fracture suggested that weekly clodronate treatment prevents bone loss and vertebral fractures in women with SH (49). However, though randomized, the study had a follow-up of only 12 months. No patient treated with clodronate experienced a new vertebral fracture during follow-up, while one subject amongst the untreated patients had a new vertebral fracture (51).

Therefore, to date, the effect of the medical therapy on the SH-related bone damage has still to be determined and specific guidelines for the management of patients with endogenous hypercortisolism are not available

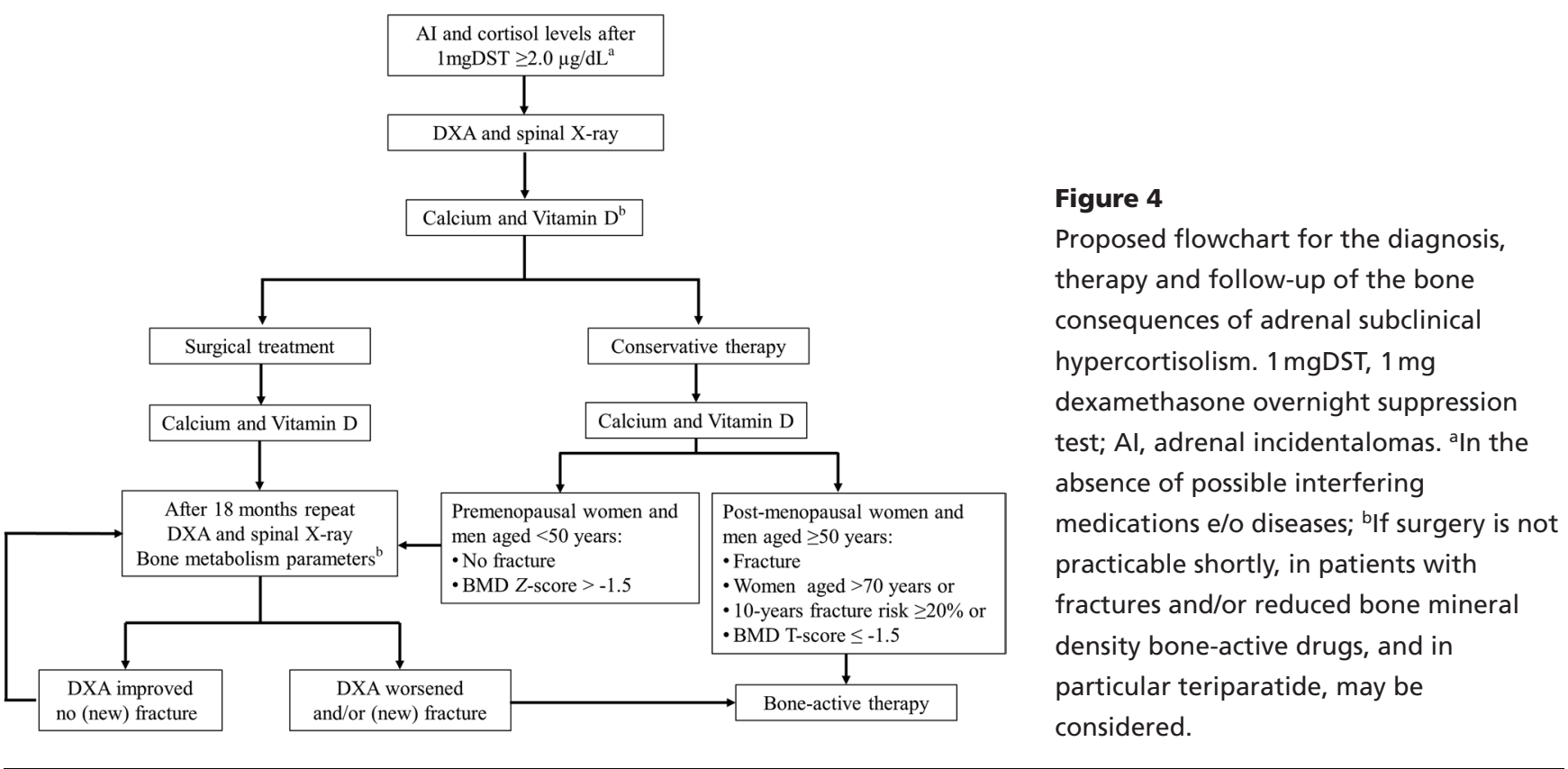


(94). As a consequence, a single-case evaluation is often needed (95). In the absence of guidelines specifically designed for patients with endogenous glucocorticoid excess, it is reasonable that physicians could refer to the guidelines for the management of osteoporosis induced by exogenous glucocorticoid administrations $(96,97)$, which are generally based on the individual fracture risk profile (calculated by FRAX) and dose of glucocorticoid used. However, it is not possible translating the corticosteroid dosages to the different degrees of endogenous hypercortisolism, and data on validation of FRAX stratification method in patients with $\mathrm{SH}$ are lacking. In addition, in patients with endogenous hypercortisolism, the removal of the cause of the cortisol excess may determine the recovery of bone health. Consequently, it is unclear whether such recommendations may be adapted to patients with hypercortisolism, and particularly with SH (95).

However, some issues deriving from studies in patients with overt hypercortisolism may be useful in patients with SH. First, all patients exposed to glucocorticoid excess should be treated with adequate supplementation of vitamin D and calcium $(96,97)$. This is particularly important in patients after the recovery from hypercortisolism (overt or subclinical), since the adequate vitamin $\mathrm{D}$ and calcium supplementation supports the rapid mineralization of the newly formed bone matrix (98). Secondly, although SH is generally diagnosed in women after menopause and rarely determines hypogonadism in males, very low bone resorption, the bisphosphonates the use of sex steroids for protecting bone in SH might be considered, at least looking at data in animal models (99). However, in patients with hypercortisolism, data regarding the protective role of sex steroids replacement therapy on bone are lacking and sex steroids administration might potentially worsen the cardiovascular risk. Thirdly, a reduced GH reserve has been described in patients with both overt cortisol excess (100) and SH (66), and the GH deficit has been associated with osteoporosis and fragility fractures (101). In patients with SH, the GH reserve seems to recover shortly after the normalization of cortisol levels (66), but if these patients are conservatively managed, the GH deficit may persist for many years. Thus, theoretically, GH treatment could be an option in patients with $\mathrm{SH}$-induced osteoporosis (102). However, this therapy has potential drawbacks as both recombinant GH and cortisol excess may induce insulin resistance that may potentially result in glucose intolerance (103).
In the absence of widely accepted guidelines on the use of bone-active drugs in endogenous cortisol excess, the approach proposed by the experts of the Altogether to Beat Cushing's syndrome (ABC) Group for the management of patients with clinically overt hypercortisolism (95) might also be largely applied to $\mathrm{SH}$ patients, given that the pathogenesis and the risk of fracture in $\mathrm{SH}$ are comparable to those with clinically overt hypercortisolism (Fig. 2). Therefore, premenopausal women or men aged $<50$ years, in the absence of fractures and BMD reduction, are at low risk and should be treated with only calcium and vitamin D if recovery from hypercortisolism is rapidly expected. A bone-active treatment may be considered in patients who do not undergo surgery and who are older than 70 years of age or in postmenopausal women or men older than 50 years with a fragility fracture and/or a FRAX calculated 10-year risk for fractures $\geq 20 \%$ and/ or with BMD $T$-score $<-1.5$. In addition, a boneactive drug should be considered in both low risk and not surgically treated patients and surgically treated patients in the presence of a fragility fracture and/or the BMD decrease during the follow-up.

The ideal drug in the condition of SH should be able to counteract the negative skeletal effects of glucocorticoids, without impairing the recovery of bone remodeling after resolution of the cortisol excess. It is known that, bisphosphonates, denosumab and teriparatide are effective in counteracting the negative effects of glucocorticoids on bone (96, $97,104)$. The available data in patients with the endogenous hypercortisolism suggest that alendronate and clodronate have positive effects on BMD (49, 105), but in this clinical context, their antifracture effect is unknown. At diagnosis, the patients with endogenous cortisol excess present with a reduced bone apposition and normal or only slightly increased bone resorption. Therefore, the bisphosphonates, by further suppressing bone turnover, in theory could favor the occurrence of rare undesired effects, such as atypical subtrochanteric fractures and osteonecrosis of the jaw, which are, moreover, more frequent in the condition of glucocorticoid excess (106). In addition, the bisphosphonates have a long-term antiresorptive effect, which may negatively influence the recovery of bone apposition after the correction of hypercortisolism. However, in SH patients without very low bone resorption, the bisphosphonates could re-establish the balance between formation and resorption and could be successfully used. At variance, Denosumab, given 
its rapid and transient antiresorptive effect, could be used for a short-term treatment in patients waiting for the definitive cure of the endogenous hypercortisolism, even though it must be underlined that, currently, this would be an off-label use of the drug (107). However, since the inhibition of bone, apposition is the main pathophysiological mechanism leading to bone loss in patients with endogenous hypercortisolism (103), teriparatide should be considered the best drug to treat skeletal fragility in patients with hypercortisolism $(106,108)$. However, the effectiveness and long-term safety of teriparatide in patients with endogenous hypercortisolism have been scarcely investigated, even in consideration that the adrenal cortisol secretion may be increased by the use of this drug (109). In addition, it is important that the potential malignant nature of the adrenal tumor is definitely excluded before the therapy with teriparatide is initiated. Finally, although data on animal models suggest the possible use of strontium ranelate in the glucocorticoid-induced osteoporosis (110), data on the efficacy of strontium ranelate in patients with hypercortisolism are not available. However, given that this drug is associated with an increased risk of cardiovascular events, it is probably not safe to suggest this drug in SH patients, who themselves already are at increased risk of cardiovascular disease.

In summary, in patients at low risk for fracture and in whom the cortisol excess is expected to be rapidly corrected, an antiosteoporotic drug is not needed and only calcium and vitamin $\mathrm{D}$ should be given. In patients conservatively treated at high risk for fracture and in patients in whom the surgical treatment has to be postponed, an antiosteoporotic drug in addition to calcium and vitamin D should be started. In these patients, teriparatide could be the drug of choice, in spite of its high cost; it should be reserved for patients at very high risk of clinical fracture (i.e. with prevalent asymptomatic vertebral fractures).

The need of a bone-active drug after the recovery from endogenous hypercortisolism has been advocated on the basis of data showing that the risk of fractures remains high within 2 years from surgery (111). However, it must be considered that in the past years, the daily dose of steroid replacement was definitely higher than that currently used (112), and, therefore, these data have probably been biased by an overtreatment of postsurgical hypoadrenalism. In addition, the usefulness of bisphosphonates after recovery from endogenous hypercortisolism is questioned (113). Therefore, after recovery from $\mathrm{SH}$, a bone-active drug should be initiated

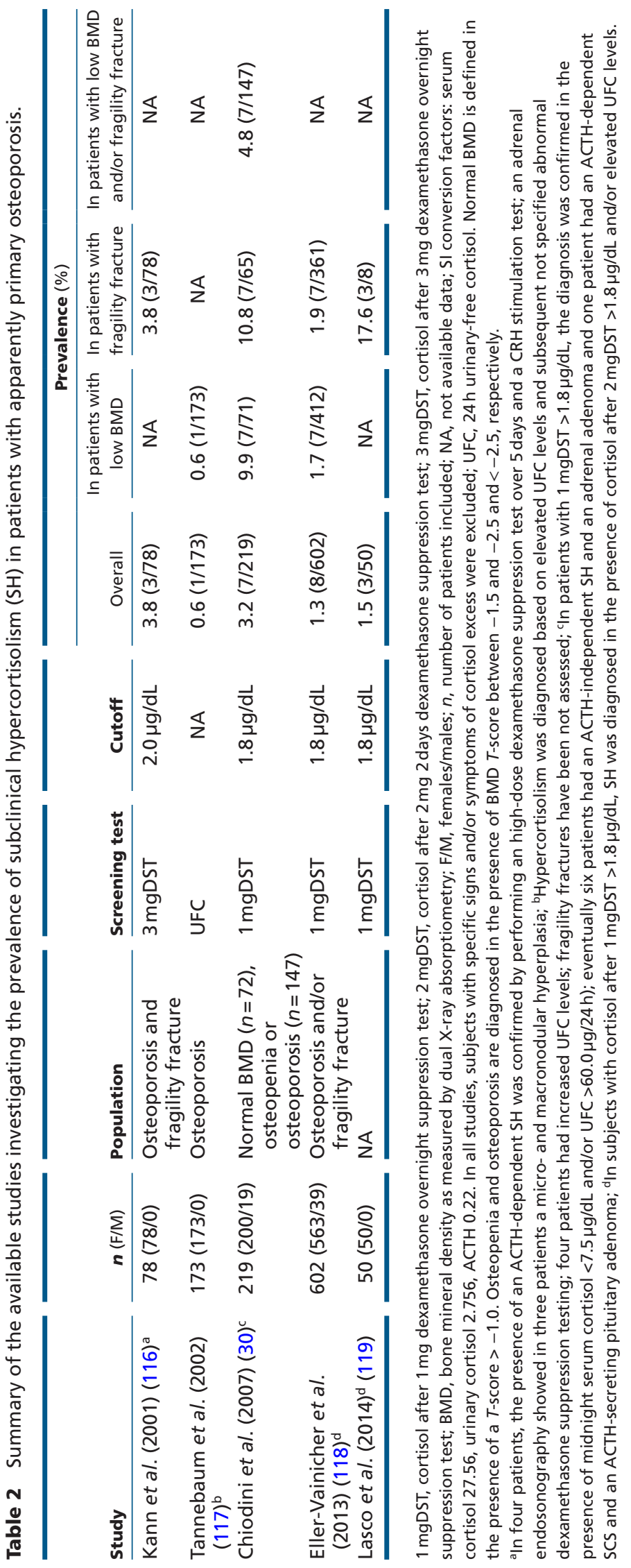

www.eje-online.org 
only in the presence of BMD decrease and/or if a fragility fracture occurs during follow-up (Fig. 2).

\section{Prevalence of the endogenous form of SH in patients with apparent primary osteoporosis}

It has been known for many years that a condition of otherwise asymptomatic hypercortisolism may present itself with the occurrence of a fragility vertebral fracture and/or unexplained osteoporosis as unique sign $(31,114$, 115). In addition, given the recent evidences showing that SH is definitely more frequent than clinically overt cortisol excess and that $\mathrm{SH}$ is associated with an increased risk of osteoporosis and fragility fractures, several studies have been designed for assessing the prevalence of an otherwise asymptomatic $\mathrm{SH}$ in patients with osteoporosis $(30,116,117,118,119)$.

Table 2 summarizes the studies specifically designed for assessing the prevalence of $\mathrm{SH}$ among patients with apparent primary osteoporosis. As shown, $\mathrm{SH}$ prevalence in the osteoporotic population varies from 0.6 to $3.8 \%$ and from 1.9 to $17.6 \%$ in patients with osteoporosis and vertebral fractures. The differences in SH prevalence are probably due to the different screening tests, setting of the studies and type and sample size of the population studied. The only study that failed to find an increased prevalence of SH among osteoporotic patients screened a sample of osteoporotic women by determining the UFC levels (117), which are notoriously not sensitive enough to detect SH $(3,31,59)$. With the exception of that study, in all other studies, SH has been screened using cortisol levels after $1 \mathrm{mgDST}$ with a cutoff of $1.8-2.0 \mu \mathrm{g} / \mathrm{dL}$ ( $50-55 \mathrm{nmol} / \mathrm{L}$ ) and, subsequently, SH has been confirmed by commonly used additional second-line tests. Using this protocol, SH prevalence among patients referred to an outpatient clinic for osteoporosis was between 1.3 and $3.8 \%$, but in two studies reached almost 11 and $18 \%$ when the screening was confined to patients with fragility fracture. However, it must be considered that these latter studies have been conducted in tertiary care centers for osteoporosis and metabolic bone diseases (30,
119) and that SH was searched for after all other possible causes of secondary osteoporosis had been excluded. Finally, the different sample size of the available studies (between 80 and 600 patients) may have influenced these results. Notwithstanding these limitations, data on SH prevalence in osteoporosis are in keeping with data on SH prevalence in other populations that might be at increased risk of $\mathrm{SH}$, such as in patients with diabetes or hypertension. Indeed, the presence of $\mathrm{SH}$ was described in $2.1-5.5 \%$ of diabetic patients $(120,121)$ and in up to $8 \%$ of the hypertensive patients $(122,123)$.

Overall, it is possible to hypothesize that $1-4 \%$ of patients with apparently primary osteoporosis has, in fact, a slight cortisol excess. Given that $\mathrm{SH}$ is a potentially removable condition, the possibility of $\mathrm{SH}$ screening in populations at risk is a matter of debate $(124,125)$. In our opinion, the current evidences do not consent to extend SH screening to all patients with osteoporosis and/or fragility fracture as a first-line test. Table 3 summarizes the indications for SH screening in patients with osteoporosis and/or fragility fractures as suggested by some leading experts. As shown, it is reasonable to screen for $\mathrm{SH}$ in all subjects with low BMD as compared with age- and weight-matched controls and/or if BMD declines more rapidly than expected and/or if it fails to respond to appropriate therapy and/or in the presence of fragility fractures in eugonadal persons $(126,127)$. Importantly, the precocious diagnosis of SH may help to prevent also the extra-skeletal consequences of this condition of subtle hypercortisolism (128).

\section{Conclusions}

The literature evidence clearly shows that AI patients with $\mathrm{SH}$ are at high risk of osteoporosis and fragility fractures and that the presence of $\mathrm{SH}$ should be always suspected in patients with established and otherwise unexplainable osteoporosis. These data are important from a clinical point of view, since in the management of patients with $\mathrm{SH}$, the possible bone damage should be taken into account, and in the management of patients

Table 3 Indication for the screening of subclinical hypercortisolism (SH) in patients with apparently primary osteoporosis.

Low BMD as compared with age- and weight-matched controls $(Z$-score $<-2.0)$

BMD declines more rapidly than expected

BMD fails to respond to appropriate therapy

Presence of a fragility fracture in eugonadal males

Presence of a fragility fractures in premenopausal females

$\mathrm{BMD}$, bone mineral density; Z-score, number of standard deviations above or below what is normally expected for age, sex and ethnic or racial origin. 
with established osteoporosis, the presence of SH should be suspected.

From a pathophysiological point of view, the condition of $\mathrm{SH}$ in AI patients may represent a pure form of slight cortisol excess. Differently from the exogenous hypercortisolism, in the endogenous hypercortisolism, the confounding effect of the diseases for which the glucocorticoids are given is absent (129). Therefore, studying the bone involvement in AI patients with $\mathrm{SH}$ may consent to assess some important aspects of the pure effect of glucocorticoid on bone, such as the role of the individual sensitivity to glucocorticoid excess.

This field of research will probably be important not only in the condition of glucocorticoid excess but in general in several diseases characterized by enhanced, though still normal, cortisol secretion such as in diabetes $(72,78)$ but also in some crucial phases of the life for bones. Indeed, recent data show that in healthy children, higher glucocorticoid secretion in the physiological range is associated with loer bone strength at the proximal radius (130), and that in the early postmenopausal period, several parameters of cortisol secretion are associated with BMD (131).

Finally, if the importance of the glucocorticoid secretion and sensitivity for bone health will be confirmed in future studies, it will be possible to personalize the clinical work-up on the basis of the individual risk of fracture and to try to counteract in some patients the adverse effect of the relatively increased cortisol secretion with the 11ßHSD1 inhibitors. Indeed, some studies showed that the inhibition of the $11 \beta \mathrm{HSD} 1$ may protect bone against the deleterious effects of glucocorticoids $(82,83,132)$.

In conclusion, physicians should keep in mind that $\mathrm{SH}$, although asymptomatic, is not a harmless condition and the research should face the problem of the SH diagnosis and medical therapy.

\section{Declaration of interest}

All authors declare that there is no conflict of interest that could be perceived as prejudicing the impartiality of the review.

\section{Funding}

This research did not receive any specific grant from any funding agency in the public, commercial or not-for-profit sector.

\section{References}

1 Reincke M. Subclinical Cushing's syndrome. Endocrinology and Metabolism Clinics of North America 200029 47-56. (doi:10.1016/ S0889-8529(05)70115-8)
2 Terzolo M, Reimondo G, Bovio S \& Angeli A. Subclinical Cushing's syndrome. Pituitary 20047 217-223. (doi:10.1007/s11102-0054024-6)

3 Chiodini I. Clinical review: diagnosis and treatment of subclinical hypercortisolism. Journal of Clinical Endocrinology and Metabolism 201196 1223-1236. (doi:10.1210/jc.2010-2722)

4 Terzolo M, Pia A \& Reimondo G. Subclinical Cushing's syndrome: definition and management. Clinical Endocrinology 201276 12-18. (doi:10.1111/cen.2011.76.issue-1)

5 De Leo M, Cozzolino A, Colao A \& Pivonello R. Subclinical Cushing's syndrome. Best Practice \& Research Clinical Endocrinology \& Metabolism 201226 497-505. (doi:10.1016/j.beem.2012.02.001)

6 Ton FN, Gunawardene SC, Lee H \& Neer RM. Effects of low-dose prednisone on bone metabolism. Journal of Bone and Mineral Research 200520 464-470. (doi:10.1359/jbmr.041125)

7 van Staa TP, Leufkens HG \& Cooper C. The epidemiology of corticosteroid-induced osteoporosis: a meta-analysis. Osteoporosis International 200213 777-787. (doi:10.1007/s001980200108)

8 Loke YL, Cavallazzi R \& Singh S. Risk of fractures with inhaled corticosteroids in COPD: systematic review and meta-analysis of randomised controlled trials and observational studies. Thorax 2011 66 699-708. (doi:10.1136/thx.2011.160028)

9 Zelissen PM, Croughs RJ, van Rijk PP \& Raymakers JA. Effect of glucocorticoid replacement therapy on bone mineral density in patients with Addison disease. Annals of Internal Medicine 1994120 207-210. (doi:10.7326/0003-4819-120-3-199402010-00005)

10 Jodar E, Valdepenas MP, Martinez G, Jara A \& Hawkins F. Long term follow-up of bone mineral density in Addison's disease. Clinical Endocrinology 200358 617-620. (doi:10.1046/j.13652265.2003.01761.x)

11 Koetz KR, Ventz M, Diederich S \& Quinkler M. Bone mineral density is not significantly reduced in adult patients on low-dose glucocorticoid replacement therapy. Journal of Clinical Endocrinology and Metabolism 201297 85-92. (doi:10.1210/jc.2011-2036)

12 Ragnarsson O, Nyström HF \& Johannsson G. Glucocorticoid replacement therapy is independently associated with reduced bone mineral density in women with hypopituitarism. Clinical Endocrinology 201276 246-252. (doi:10.1111/j.13652265.2011.04174.x)

13 Falhammar H, Filipsson H, Holmdahl G, Janson PO, Nordenskjöld A, Hagenfeldt $\mathrm{K} \&$ Thorén MJ. Fractures and bone mineral density in adult women with 21-hydroxylase deficiency. Journal of Clinical Endocrinology and Metabolism 200792 4643-4649. (doi:10.1210/ jc.2007-0744)

14 King JA, Wisniewski AB, Bankowski BJ, Carson KA, Zacur HA \& Migeon CJ. Long-term corticosteroid replacement and bone mineral density in adult women with classical congenital adrenal hyperplasia. Journal of Clinical Endocrinology and Metabolism 200691 865-869. (doi:10.1210/jc.2005-0745)

15 Terzolo M, Bovio S, Reimondo G, Pia A, Osella G, Borretta G \& Angeli A. Subclinical Cushing's syndrome in adrenal incidentalomas. Endocrinology and Metabolism Clinics of North America 200534 423-439. (doi:10.1016/j.ecl.2005.01.008)

16 Mantero F, Terzolo M, Arnaldi G, Osella G, Masini AM, Alì A, Giovagnetti M, Opocher G \& Angeli A. A survey on adrenal incidentaloma in Italy. Journal of Clinical Endocrinology and Metabolism 200085 637-644. (doi:10.1210/jc.85.2.637)

17 Grumbach MM, Biller BM, Braunstein GD, Campbell KK, Carney JA, Godley PA, Harris EL, Lee JK, Oertel YC, Posner MC et al. Management of the clinically inapparent adrenal masses ("incidentaloma"). Annals of Internal Medicine 2003138 424-429. (doi:10.7326/0003-4819-138-5-200303040-00013)

18 Nawar R \& Aron D. Adrenal incidentalomas - a continuing management dilemma. Endocrine-Related Cancer 200512 585-598. (doi:10.1677/erc.1.00951) 
19 Griffing GT. Editorial A-I-D-S: the new endocrine epidemic. Journal of Clinical Endocrinology and Metabolism 199479 1530-1531. (doi:10.1210/jc.79.6.1530)

20 Glazer HS, Weyman PJ, Sagel SS, Levitt RG \& McClennan BL. Nonfunctioning adrenal masses: incidental discovery on computed tomography. American Journal of Roentgenology 1982139 81-85. (doi:10.2214/ajr.139.1.81)

21 Bovio S, Cataldi A, Reimondo G, Sperone P, Novello S, Berruti A, Borasio P, Fava C, Dogliotti L, Scagliotti GV et al. Prevalence of adrenal incidentaloma in a contemporary computerized tomography series. Journal of Endocrinological Investigation 200629 298-302. (doi:10.1007/BF03344099)

22 Freda PU, Beckers AM, Katznelson L, Molitch ME, Montori VM, Post KD \& Vance ML. Pituitary incidentaloma: an endocrine society clinical practice guideline. Journal of Clinical Endocrinology and Metabolism 201196 894-904. (doi:10.1210/jc.2010-1048)

23 Toini A, Dolci A, Ferrante E, Verrua E, Malchiodi E, Sala E, Lania AG Chiodini I, Beck-Peccoz P, Arosio M et al. Screening for ACTHdependent hypercortisolism in patients affected with pituitary incidentaloma. European Journal of Endocrinology 2015172 363-369. (doi:10.1530/EJE-14-0599)

24 Chiodini I, Torlontano M, Carnevale V, Trischitta V \& Scillitani A. Skeletal involvement in adult patients with endogenous hypercortisolism. Journal of Endocrinological Investigation $2008 \mathbf{3 1}$ 267-276. (doi:10.1007/BF03345601)

25 Chiodini I, Francucci CM \& Scillitani A. Densitometry in glucocorticoid-induced osteoporosis. Journal of Endocrinological Investigation. 200831 33-37.

26 Chiodini I, Morelli V, Masserini B, Salcuni AS, Eller-Vainicher C, Viti R, Coletti F, Guglielmi G, Battista C, Carnevale V et al. Bone mineral density, prevalence of vertebral fractures and bone quality in patients with adrenal incidentalomas with and without subclinical hypercortisolism: an Italian Multicenter Study. Journal of Clinical Endocrinology and Metabolism 200994 3207-3214. (doi:10.1210/ jc.2009-0468)

27 Eller-Vainicher C, Morelli V, Ulivieri FM, Palmieri S, Zhukouskaya VV, Cairoli E, Pino R, Naccarato A, Scillitani A, Beck-Peccoz P et al. Bone quality, as measured by trabecular bone score in patients with adrenal incidentalomas with and without subclinical hypercortisolism. Journal of Bone and Mineral Research 201227 2223-2230. (doi:10.1002/jbmr.1648)

28 Morelli V, Donadio F, Eller-Vainicher C, Cirello V, Olgiati L, Savoca C, Cairoli E, Salcuni AS, Beck-Peccoz P \& Chiodini I. Role of glucocorticoid receptor polymorphism in adrenal incidentalomas. European Journal of Clinical Investigation 201040 803-811. (doi:10.1111/eci.2010.40.issue-9)

29 Zhukouskaya VV, Eller-Vainicher C, Gaudio A, Cairoli E, Ulivieri FM, Palmieri S, Morelli V, Orsi E, Masserini B, Barbieri AM et al. In postmenopausal female subjects with type 2 diabetes mellitus, vertebral fractures are independently associated with cortisol secretion and sensitivity. Journal of Clinical Endocrinology and Metabolism 2015100 1417-1425. (doi:10.1210/ jc. 2014-4177)

30 Chiodini I, Mascia ML, Muscarella S, Battista C, Minisola S, Arosio M, Santini SA, Guglielmi G, Carnevale V \& Scillitani A. Subclinical hypercortisolism among outpatients referred for osteoporosis. Annals of Internal Medicine 2007147 541-548. (doi:10.7326/0003-4819-147-8-200710160-00006)

31 Arnaldi G, Angeli A, Atkinson AB, Bertagna X, Cavagnini F, Chrousos GP, Fava GA, Findling JW, Gaillard RC, Grossman AB et al. Diagnosis and complications of Cushing's syndrome: a consensus statement. Journal of Clinical Endocrinology and Metabolism $2003 \mathbf{8 8}$ 5593-5602. (doi:10.1210/jc.2003-030871)

32 Osella G, Terzolo M, Reimondo G, Piovesan A, Pia A, Termine A, Paccotti P \& Angeli A. Serum markers of bone and collagen turnover in patients with Cushing's syndrome and in subjects with adrenal incidentalomas. Journal of Clinical Endocrinology and Metabolism 1997 82 3303-3307. (doi:10.1210/jc.82.10.3303)

33 Sartorio A, Conti A, Ferrero S, Giambona S, Re T, Passini E \& Ambrosi B. Evaluation of markers of bone and collagen turnover in patients with active and preclinical Cushing's syndrome and in patients with adrenal incidentaloma. European Journal of Endocrinology 1998138 146-152. (doi:10.1530/eje.0.1380146)

34 Torlontano M, Chiodini I, Pileri M, Guglielmi G, Cammisa M, Modoni S, Carnevale V, Trischitta V \& Scillitani A. Altered bone mass and turnover in female patients with adrenal incidentalomas: the effect of subclinical hypercortisolism. Journal of Clinical Endocrinology and Metabolism 199984 2381-2385. (doi:10.1210/jcem.84.7.5856)

35 Chiodini I, Torlontano M, Carnevale V, Guglielmi G, Cammisa M, Trischitta V \& Scillitani A. Bone loss rate in adrenal incidentalomas: a longitudinal study. Journal of Clinical Endocrinology and Metabolism 200186 5337-5341. (doi:10.1210/jc.86.11.5337)

36 Francucci CM, Pantanetti P, Garrapa GG, Massi F, Arnaldi G \& Mantero F. Bone metabolism and mass in women with Cushing's syndrome and adrenal incidentaloma. Clinical Endocrinology 200257 587-593. (doi:10.1046/j.1365-2265.2002.01602.x)

37 Tauchmanovà L, Pivonello R, De Martino MC, Rusciano A, De Leo M, Ruosi C, Mainolfi C, Lombardi G, Salvatore M \& Colao A. Effects of sex steroids on bone in women with subclinical or overt endogenous hypercortisolism. European Journal of Endocrinology 2007 157 359-366. (doi:10.1530/EJE-07-0137)

38 Canalis E, Mazziotti G, Giustina A \& Bilezikian JP. Glucocorticoidinduced osteoporosis: pathophysiology and therapy. Osteoporosis International 200718 1319-1328. (doi:10.1007/s00198-0070394-0)

39 Chiodini I, Tauchmanovà L, Torlontano M, Battista C, Guglielmi G Cammisa M, Colao A, Carnevale V, Rossi R, Di Lembo S et al. Bone involvement in eugonadal male patients with adrenal incidentaloma and subclinical hypercortisolism. Journal of Clinical Endocrinology and Metabolism 200287 5491-5494. (doi:10.1210/jc.2002-020399)

40 Bardet S, Rohmer V, Boux de Casson F, Coffin C, Ronci N, Sabatier JP, Lecomte P, Audran M, Henry-Amar M \& Tabarin A. Bone density and biochemical bone markers in patients with adrenal incidentalomas: effect of subclinical hypercortisolism. Revue de Médecine Interne 2002 23 508-517. (doi:10.1016/S0248-8663(02)00606-9)

41 Hadjidakis D, Tsagarakis S \& Roboti C. Does subclinical hypercortisolism adversely affect the bone mineral density of patients with adrenal incidentalomas? Clinical Endocrinology $2003 \mathbf{5 8}$ 72-77. (doi:10.1046/j.1365-2265.2003.01676.x)

42 Calvo MS, Eyre DR \& Gundberg CM. Molecular basis and clinical application of biological markers of bone turnover. Endocrine Review 199617 333-368. (doi:10.1210/er.17.4.333)

43 Tauchmanovà L, Rossi R, Nuzzo V, del Puente A, Esposito-del Puente A, Pizzi C, Fonderico F, Lupoli G \& Lombardi G. Bone loss determined by quantitative ultrasonometry correlates inversely with disease activity in patients with endogenous glucocorticoid excess due to adrenal mass. European Journal of Endocrinology $2001 \mathbf{1 4 5}$ 241-247. (doi:10.1530/eje.0.1450241)

44 Chiodini I, Guglielmi G, Battista C, Carnevale V, Torlontano M, Cammisa M, Trischitta V \& Scillitani A. Spinal volumetric bone mineral density and vertebral fractures in female patients with adrenal incidentalomas: the effect of subclinical hypercortisolism and gonadal status Journal of Clinical Endocrinology and Metabolism 200489 2237-2241. (doi:10.1210/jc.2003-031413)

45 Chiodini I, Viti R, Coletti F, Guglielmi G, Battista C, Ermetici F, Morelli V, Salcuni A, Carnevale V, Urbano F et al. Eugonadal male patients with adrenal incidentalomas and subclinical hypercortisolism have increased rate of vertebral fractures. Clinical Endocrinology 200970 208-213. (doi:10.1111/j.13652265.2008.03310.x)

46 Morelli V, Palmieri S, Salcuni AS, Eller-Vainicher C, Cairoli E, Zhukouskaya V, Scillitani A, Beck-Peccoz P \& Chiodini I. Bilateral 
and unilateral adrenal incidentalomas: biochemical and clinical characteristics. European Journal of Endocrinology $2013 \mathbf{6 8} 235-241$. (doi:10.1530/eje-12-0777)

47 Rossi R, Tauchmanova L, Luciano A, Di Martino M, Battista C, Del Viscovo L, Nuzzo V \& Lombardi G. Subclinical Cushing's syndrome in patients with adrenal incidentaloma: clinical and biochemical features. Journal of Clinical Endocrinology and Metabolism $2000 \mathbf{8 5}$ 1440-1448. (doi:10.1210/jc.85.4.1440)

48 Osella G, Reimondo G, Peretti P, Alì A, Paccotti P, Angeli A \& Terzolo M. The patients with incidentally discovered adrenal adenoma (incidentaloma) are not at increased risk of osteoporosis. Journal of Clinical Endocrinology and Metabolism 200186 604-607. (doi:10.1210/jcem.86.2.7178)

49 Tauchmanova L, Guerra E, Pivonello R, De Martino MC, De Leo M, Caggiano F, Lombardi G \& Colao A. Weekly clodronate treatment prevents bone loss and vertebral fractures in women with subclinical Cushing's syndrome. Journal of Endocrinological Investigation 200932 390-394. (doi:10.1007/BF03346473)

50 Morelli V, Eller-Vainicher C, Salcuni AS, Coletti F, Iorio L, Muscogiuri G, Della Casa S, Arosio M, Ambrosi B, Beck-Peccoz P et al. Risk of new vertebral fractures in patients with adrenal incidentaloma with and without subclinical hypercortisolism: a multicenter longitudinal study. Journal of Bone and Mineral Research 201126 1816-1821. (doi:10.1002/jbmr.398)

51 Salcuni AS, Morelli V, Eller-Vainicher C, Palmieri S, Cairoli E, Spada A, Scillitani A \& Chiodini I. Adrenalectomy reduces the risk of vertebral fractures in patients with monolateral adrenal incidentalomas and subclinical hypercortisolism. European Journal of Endocrinology 2016174 261-269. (doi:10.1530/EJE15-0977)

52 Morelli V, Eller-Vainicher C, Palmieri S, Cairoli E, Salcuni AS, Scillitani A, Carnevale V, Corbetta S, Arosio M, Della Casa S et al. Prediction of vertebral fractures in patients with monolateral adrenal incidentalomas. Journal of Clinical Endocrinology and Metabolism 2016 101 2768-2775. (doi:10.1210/jc.2016-1423)

53 Thomsen JS, Ebbesen EN \& Mosekilde L. Predicting human vertebral bone strength by vertebral static histomorphometry. Bone $2002 \mathbf{3 0}$ 502-508. (doi:10.1016/S8756-3282(01)00702-5)

54 Link TM, Majumdar S, Grampp S, Guglielmi G, van Kuijk C, Imhof H, Glueer C \& Adams JE. Imaging of trabecular bone structure in osteoporosis. European Journal of Radiology 19999 1781-1788. (doi:10.1007/s003300050922)

55 Crans GG, Genant HK \& Krege JH. Prognostic utility of a semiquantitative spinal deformity index. Bone 200537 175-179. (doi:10.1016/j.bone.2005.04.003)

56 Genant HK, Delmas PD, Chen P, Jiang Y, Eriksen EF, Dalsky GP, Marcus R \& San Martin J. Severity of vertebral fracture reflects deterioration of bone microarchitecture. Osteoporosis International 200718 69-76. (doi:10.1007/s00198-006-0199-6)

57 Bousson V, Bergot C, Sutter B, Levitz P \& Cortet B. The Scientific Committee of the GRIO (Groupe de Recherche et d'Information sur les Oste'oporoses). Trabecular bone score (TBS); available knowledge, clinical relevance, and future prospects. Osteoporosis International 201223 1489-1501. (doi:10.1007/ s00198-011-1824-6)

58 Hans D, Barthe N, Boutroy S, Pothuaud L, Winzenrieth R \& Krieg MA. Correlations between trabecular bone score, measured using anteroposterior dual X-ray absorptiometry acquisition, and 3-dimensional parameters of bone microarchitecture: an experimental study on human cadaver vertebrae. Journal of Clinical Densitometry 201114 302-312. (doi:10.1016/j. jocd.2011.05.005)

59 Morelli V \& Chiodini I. Subclinical hypercortisolism: how to deal with it? Frontiers of Hormone Research 201646 28-38. (doi:10.1159/ issn.0301-3073)
60 Frenkel B, White W \& Tuckermann J. Glucocorticoid-induced osteoporosis. Advances in Experimental Medicine and Biology 2015872 179-215. (doi:10.1007/978-1-4939-2895-8)

61 Canalis E. Mechanism of glucocorticoid action in bone: implications to glucocorticoid-induced osteoporosis. Journal of Clinical Endocrinology and Metabolism 199681 3441-3447. (doi:10.1210/ jcem.81.10.8855781)

62 Henneicke H, Gasparini SJ, Brennan-Speranza TC, Zhou H \& Seibel MJ. Glucocorticoids and bone: local effects and systemic implications. Trends in Endocrinology and Metabolism 201425 197-211. (doi:10.1016/j.tem.2013.12.006)

63 Mazziotti G \& Giustina A. Glucocorticoids and the regulation of growth hormone secretion. Nature Review Endocrinology 20139 265-276. (doi:10.1038/nrendo.2013.5)

64 Terzolo M, Bossoni S, Alí A, Doga M, Reimondo G, Milani G, Peretti P, Manelli F, Angeli A \& Giustina A. Growth hormone (GH) responses to $\mathrm{GH}$-releasing hormone alone or combined with arginine in patients with adrenal incidentaloma: evidence for enhanced somatostatinergic tone. Journal of Clinical Endocrinology and Metabolism 200085 1310-1315. (doi:10.1210/jc.85.3.1310)

65 Tzanela M, Zianni D, Stylianidou Ch, Karavitaki N, Tsagarakis S \& Thalassinos NC. Evaluation of GH reserve in patients with adrenal incidentalomas and biochemical evidence of subclinical autonomous glucocorticoid hypersecretion. Clinical Endocrinology 200562 597-602. (doi:10.1111/cen.2005.62.issue-5)

66 Palmieri S, Morelli V, Salcuni AS, Eller-Vainicher C, Cairoli E, Zhukouskaya VV, Beck-Peccoz P, Scillitani A \& Chiodini I. GH secretion reserve in subclinical hypercortisolism. Pituitary 201417 470-476. (doi:10.1007/s11102-013-0528-7)

67 Haden ST, Glowacki J, Hurwitz S, Rosen C \& LeBoff MS. Effects of age on serum dehydroepiandrosterone sulphate, IGF-1, and IL-6 levels in women. Calcified Tissue International 200066 414-418. (doi:10.1007/s002230010084)

68 Minetto M, Reimondo G, Osella G, Ventura M, Angeli A \& Terzolo M. Bone loss is more severe in primary adrenal than in pituitary-dependent Cushing's syndrome. Osteoporosis International 200411 855-861. (doi:10.1007/s00198-004-1616-3)

69 Tauchmanovà L, Pivonello R, Di Somma C, Rossi R, De Martino MC, Camera L, Klain M, Salvatore M, Lombardi G \& Colao A. Bone demineralization and vertebral fractures in endogenous cortisol excess: role of disease etiology and gonadal status. Journal of Clinical Endocrinology and Metabolism 200691 1779-1784. (doi:10.1210/ jc.2005-0582)

70 Vestergaard P, Lindholm J, Jørgensen JO, Hagen C, Hoeck HC, Laurberg P, Rejnmark L, Brixen K, Kristensen Lø, Feldt-Rasmussen U et al. Increased risk of osteoporotic fractures in patients with Cushing's syndrome. European Journal of Endocrinology 2002146 51-56. (doi:10.1530/eje.0.1460051)

71 Peng YM, Lei SF, Guo Y, Xiong DH, Yan H, Wang L, Guo YF \& Deng HW. Sex-specific association of the glucocorticoid receptor gene with extreme BMD. Journal of Bone and Mineral Research 2008 23 247-252. (doi:10.1359/jbmr.071017)

72 Zhukouskaya VV, Eller-Vainicher C, Gaudio A, Cairoli E, Ulivieri FM, Palmieri S, Morelli V, Orsi E, Masserini B, Barbieri AM et al. In postmenopausal female subjects with type 2 diabetes mellitus, vertebral fractures are independently associated with cortisol secretion and sensitivity. Journal of Clinical Endocrinology and Metabolism 2015100 1417-1425. (doi:10.1210/ jc.2014-4177)

73 Huizenga NA, Koper JW, De Lange P, Pols HA, Stolk RP, Burger H, Grobbee DE, Brinkmann AO, De Jong FH \& Lamberts SW. A polymorphism in the glucocorticoid receptor gene may be associated with and increased sensitivity to glucocorticoids in vivo. Journal of Clinical Endocrinology and Metabolism 199883 144-151. (doi:10.1210/jc.83.1.144) 
74 van Schoor NM, Dennison E, Lips P, Uitterlinden AG \& Cooper C. Serum fasting cortisol in relation to bone, and the role of genetic variations in the glucocorticoid receptor. Clinical Endocrinology 2007 67 871-878. (doi:10.1111/j.1365-2265.2007.02978.x)

75 van Rossum EF, Voorhoeve PG, de Velde SJ, Koper JW, Delemarrevan de Waal HA, Kemper HC \& Lamberts SW. The ER22/23EK polymorphism in the glucocorticoid receptor gene is associated with a beneficial body composition and muscle strength in young adults. Journal of Clinical Endocrinology and Metabolism 200489 4004-4009. (doi:10.1210/jc.2003-031422)

76 Szappanos A, Patocs A, Toke J, Boyle B, Sereg M, Majnik J, Borgulya G, Varga I, Likó I, Racz K et al. BclI polymorphism of the glucocorticoid receptor gene is associated with decreased bone mineral density in patients with endogenous hypercortisolism. Clinical Endocrinology 200971 636-643. (doi:10.1111/cen.2009.71. issue-5)

77 Trementino L, Appolloni G, Ceccoli L, Marcelli G, Concettoni C, Boscaro M \& Arnaldi G. Bone complications in patients with Cushing's syndrome: looking for clinical, biochemical, and genetic determinants. Osteoporosis International 201425 913-921. (doi:10.1007/s00198-013-2520-5)

78 Chiodini I, Di Lembo S, Morelli V, Epaminonda P, Coletti F, Masserini B, Scillitani A, Arosio M \& Adda G. Hypothalamicpituitary-adrenal activity in type 2 diabetes mellitus: role of autonomic imbalance. Metabolism 200655 1135-1140. (doi:10.1016/j.metabol.2006.04.010)

79 Tzanela M, Mantzou E, Saltiki K, Tampourlou M, Kalogeris N, Hadjidakis D, Tsagarakis S \& Alevizaki M. Clinical and biochemical impact of BCL1 polymorphic genotype of the glucocorticoid receptor gene in patients with adrenal incidentalomas. Journal of Endocrinological Investigation 201235 395-400.

80 Tomlinson JW, Walker EA, Bujalska IJ, Draper N, Lavery GG, Cooper MS, Hewison M \& Stewart PM. 11 $\beta$-Hydroxysteroid dehydrogenase type 1: a tissue specific regulator of glucocorticoid response. Endocrine Review 200425 831-866. (doi:10.1210/er.20030031)

81 Cooper MS. 11beta-Hydroxysteroid dehydrogenase: a regulator of glucocorticoid response in osteoporosis. Journal of Endocrinological Investigation 200831 16-21. (doi:10.1007/BF03345561)

82 Park JS, Bae SJ, Choi SW, Son YH, Park SB, Rhee SD, Kim HY, Jung WH, Kang SK, Ahn JH et al. A novel 11ß-HSD1 inhibitor improves diabesity and osteoblast differentiation. Journal of Molecular Endocrinology 201452 191-202. (doi:10.1530/ JME-13-0177)

83 Wu L, Qi H, Zhong Y, Lv S, Yu J, Liu J, Wang L, Bi J, Kong X, Di W et al. 11ß-Hydroxysteroid dehydrogenase type 1 selective inhibitor BVT.2733 protects osteoblasts against endogenous glucocorticoid induced dysfunction. Endocrine Journal 201360 1047-1058. (doi:10.1507/endocri.EJ12-0376)

84 Feldman K, Szappanos A, Butz H, Grolmusz V, Majnik J, Likó I, Kriszt B, Lakatos P, Tóth M, Rácz K et al. The rs4844880 polymorphism in the promoter region of the HSD11B1 gene associates with bone mineral density in healthy and postmenopausal osteoporotic women. Steroids 201277 1345-1351. (doi:10.1016/j. steroids.2012.08.014)

85 Siggelkow H, Etmanski M, Bozkurt S, Gro $\beta$ P, Koepp R, Brockmöller J

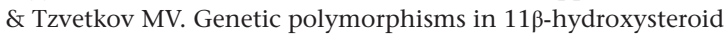
dehydrogenase type 1 correlate with the postdexamethasone cortisol levels and bone mineral density in patients evaluated for osteoporosis. Journal of Clinical Endocrinology and Metabolism 201499 293-302. (doi:10.1210/jc.2013-1418)

86 Hwang JY, Lee SH, Kim GS, Koh JM, Go MJ, Kim YJ, Kim HC, Kim TH, Hong JM, Park EK et al. HSD11 1 polymorphisms predicted bone mineral density and fracture risk in postmenopausal women without clinically apparent hypercortisolemia. Bone 200945 1098-1103. (doi:10.1016/j.bone.2009.07.080)
87 Szappanos A, Patócs A, Gergics P, Bertalan R, Kerti A, Acs B, Feldmann K, Rácz K \& Tóth M. The 83,557insA variant of the gene coding $11 \beta$-hydroxysteroid dehydrogenase type 1 enzyme associates with serum osteocalcin in patients with endogenous Cushing's syndrome. Journal of Steroid Biochemistry and Molecular Biology 2011 123 79-84. (doi:10.1016/j.jsbmb.2010.11.009)

88 Morelli V, Polledri E, Mercadante R, Zhukouskaya VV, Palmieri S, Beck-Peccoz P, Spada A, Fustinoni S \& Chiodini I. The activity of $11 \beta$-Hydroxysteroid dehydrogenase type 2 enzyme and cortisol secretion in patients with adrenal incidentalomas. Endocrine 2015, epub ahead of print. (doi:10.1007/s12020-015-0763-y)

89 Tsagarakis S, Vassiliadi D \& Thalassinos N. Endogenous subclinical hypercortisolism: diagnostic uncertainties and clinical implications. Journal of Endocrinological Investigation 200629 471-482. (doi:10.1007/BF03344133)

90 Midorikawa S, Sanada H, Hashimoto S, Suzuki T \& Watanabe T. The improvement of insulin resistance in patients with adrenal incidentalomas by surgical resection. Clinical Endocrinology $2001 \mathbf{5 4}$ 797-804. (doi:10.1046/j.1365-2265.2001.01274.x)

91 Emral R, Uysal AR, Asik M, Gullu S, Corapcioglu D, Tonyukuk V \& Erdogan G. Prevalence of subclinical Cushing's syndrome in 70 patients with adrenal incidentalomas: clinical, biochemical and surgical outcomes. Endocrine Journal 200350 399-408. (doi:10.1507/ endocrj.50.399)

92 Chiodini I, Morelli V, Salcuni AS, Eller-Vainicher C, Torlontano M, Coletti F, Iorio L, Cuttitta A, Ambrosio A, Vicentini L et al. Beneficial metabolic effects of prompt surgical treatment in patients with an adrenal incidentaloma causing biochemical hypercortisolism. Journal of Clinical Endocrinology and Metabolism 201095 2736-2745. (doi:10.1210/jc.2009-2387)

93 Eller-Vainicher C, Morelli V, Salcuni AS, Battista C, Torlontano M, Coletti F, Iorio L, Cairoli E, Beck-Peccoz P, Arosio M et al. Accuracy of several parameters of hypothalamic-pituitary-adrenal axis activity in predicting before surgery the metabolic effects of the removal of an adrenal incidentaloma. European Journal of Endocrinology 2010163 925-935. (doi:10.1530/EJE-10-0602)

94 Shen J, Sun M, Zhou B \& Yan J. Nonconformity in the clinical practice guidelines for subclinical Cushing's syndrome: which guidelines are trustworthy? European Journal of Endocrinology 2014 171 421-431. (doi:10.1530/EJE-14-0345)

95 Scillitani A, Mazziotti G, Di Somma C, Moretti S, Stigliano A, Pivonello R, Giustina A, Colao A \& On Behalf of ABC Group. Treatment of skeletal impairment in patients with endogenous hypercortisolism: when and how? Osteoporosis International 201425 441-446. (doi:10.1007/s00198-013-2588-y)

96 Lekamwasam S, Adachi JD, Agnusdei D, Bilezikian J, Boonen S, Borgström F, Cooper C, Diez Perez A, Eastell R, Hofbauer LC et al. Joint IOF-ECTS GIO guidelines working group. A framework for the development of guidelines for the management of glucocorticoidinduced osteoporosis. Osteoporosis International 201223 2257-2276. (doi:10.1007/s00198-012-1958-1)

97 Grossman JM, Gordon R, Ranganath VK, Deal C, Caplan L, Chen W, Curtis JR, Furst DE, McMahon M, Patkar NM et al. American college of rheumatology 2010 recommendations for the prevention and treatment of glucocorticoid-induced osteoporosis. Arthritis Care Research 201062 1515-1526. (doi:10.1002/acr.20295)

98 Füto L, Toke J, Patócs A, Szappanos A, Varga I, Gláz E, Tulassay Z, Rácz K \& Tóth M. Skeletal differences in bone mineral area and content before and after cure of endogenous Cushing's syndrome. Osteoporosis International 200819 941-949. (doi:10.1007/s00198007-0514-x)

99 Weinstein RS, Jia D, Powers CC, Stewart SA, Jilka RL, Parfitt AM \& Manolagas SC. The skeletal effects of glucocorticoid excess override those of orchidectomy in mice. Endocrinology 2004145 1980-1987. (doi:10.1210/en.2003-1133) 
100 Mancini T, Doga M, Mazziotti G \& Giustina A. Cushing's syndrome and bone. Pituitary 20047 249-252. (doi:10.1007/ s11102-005-1051-2)

101 Mazziotti G, Porcelli T, Bianchi A, Cimino V, Patelli I, Mejia C, Fusco A, Giampietro A, De Marinis L \& Giustina A. Glucocorticoid replacement therapy and vertebral fractures in hypopituitary adult males with GH deficiency. European Journal of Endocrinology 2010 163 15-20. (doi:10.1530/EJE-10-0125)

102 Giustina A, Bussi AR, Jacobello C \& Wehrenberg WB. Effects of recombinant human growth hormone $(\mathrm{GH})$ on bone and intermediary metabolism in patients receiving chronic glucocorticoid treatment with suppressed endogenous GH response to GH-releasing hormone. Journal of Clinical Endocrinology and Metabolism 199580 122-129. (doi:10.1210/ jc.80.1.122)

103 Mazziotti G, Gazzaruso C \& Giustina A. Diabetes in Cushing syndrome: basic and clinical aspects. Trends in Endocrinology and Metabolism 201122 499-506. (doi:10.1016/j.tem.2011.09.001)

104 Dore RK, Cohen SB, Lane NE, Palmer W, Shergy W, Zhou L, Wang H, Tsuji W, Newmark R \& Denosumab RA Study Group. Effects of denosumab on bone mineral density and bone turnover in patients with rheumatoid arthritis receiving concurrent glucocorticoids or bisphosphonates. Annals of Rheumatology Diseases 201069 872-875. (doi:10.1136/ard.2009.112920)

105 Di Somma C, Colao A, Pivonello R, Klain M, Faggiano A, Tripodi FS, Merola B, Salvatore M \& Lombardi G. Effectiveness of chronic treatment with alendronate in the osteoporosis of Cushing's disease. Clinical Endocrinology 199848 655-662. (doi:10.1046/j.13652265.1998.00486.x)

106 Hansen KE, Wilson HA, Zapalowski C, Fink HA, Minisola S \& Adler RA. Uncertainties in the prevention and treatment of glucocorticoid-induced osteoporosis. Journal of Bone and Mineral Research 201126 1989-1996. (doi:10.1002/jbmr.362)

107 Cairoli E, Eller-Vainicher C \& Chiodini I. Update on Denosumab in the management of postmenopausal osteoporosis: patient preference and adherence. International Journal of Womens Health 20157 833-839. (doi:10.2147/ijwh.s75681)

108 Colao A, Tauchmanovà L, Pivonello R, Vuolo L, De Leo M, Rota F, Guerra E, Vitale P, Contaldi P, Lombardi G et al. Teriparatide treatment in osteoporosis of patients with Cushing's syndrome. ENEA Workshop Novel insights in the management of Cushing's syndrome, Naples, Italy, 4-6 December 2009.

109 Lasco A, Catalano A, Morabito N, Gaudio A, Basile G, Trifiletti A $\&$ Atteritano M. Adrenal effects of teriparatide in the treatment of severe postmenopausal osteoporosis. Osteoporosis International 2011 22 299-303. (doi:10.1007/s00198-010-1222-5)

110 Sun P, Cai DH, Li QN, Chen H, Deng WM, He L \& Yang L. Effects of alendronate and strontium ranelate on cancellous and cortical bone mass in glucocorticoid-treated adult rats. Calcified Tissue International 201086 495-501. (doi:10.1007/s00223-0109363-2)

111 Vestergaard P, Lindholm J, Jørgensen JO, Hagen C, Hoeck HC, Laurberg P, Rejnmark L, Brixen K, Kristensen LØ, Feldt-Rasmussen U et al. Increased risk of osteoporotic fractures in patients with Cushing's syndrome. European Journal of Endocrinology 2002146 51-56. (doi:10.1530/eje.0.1460051)

112 Schulz J, Frey KR, Cooper MS, Zopf K, Ventz M, Diederich S \& Quinkler M. Reduction in daily hydrocortisone dose improves bone health in primary adrenal insufficiency. European Journal of Endocrinology 2016 174 531-538. (doi:10.1530/EJE-15-1096)

113 Randazzo ME, Grossrubatscher E, Dalino Ciaramella P, Vanzulli A \& Loli P. Spontaneous recovery of bone mass after cure of endogenous hypercortisolism. Pituitary 201215 193-201. (doi:10.1007/s11102011-0306-3)

114 Arduc A, Dogan BA, Akbaba G, Dagdelen I, Kucukler K, Isik S, Ozuguz U, Berker D \& Guler S. A rare presentation of subclinical
Cushing's syndrome as a pubic fracture. Internal Medicine $2014 \mathbf{5 3}$ 1779-1782. (doi:10.2169/internalmedicine.53.1489)

115 Khanine V, Fournier JJ, Requeda E, Luton JP, Simon F \& Crouzet J. Osteoporotic fractures at presentation of Cushing's disease: two case reports and a literature review. Joint Bone Spine 200067 341-345.

116 Kann P, Laudes M, Piepkorn B, Heintz A \& Beyer J. Suppressed levels of serum cortisol following high-dose oral dexamethasone administration differ between healthy postmenopausal females and patients with established primary vertebral osteoporosis. Clinical Rheumatology 200120 25-29. (doi:10.1007/ s100670170099)

117 Tannenbaum C, Clark J, Schwartzman K, Wallenstein S, Lapinski R, Meier D \& Luckey M. Yield of laboratory testing to identify secondary contributors to osteoporosis in otherwise healthy women. Journal of Clinical Endocrinology and Metabolism 200287 4431-4437. (doi:10.1210/jc.2002-020275)

118 Eller-Vainicher C, Cairoli E, Zhukouskaya VV, Morelli V, Palmieri S, Scillitani A, Beck-Peccoz P \& Chiodini I. Prevalence of subclinical contributors to low bone mineral density and/or fragility fracture. European Journal of Endocrinology 2013169 225-237. (doi:10.1530/ EJE-13-0102)

119 Lasco A, Catalano A, Pilato A, Basile G, Mallamace A \& Atteritano M. Subclinical hypercortisol-assessment of bone fragility: experience of single osteoporosis center in Sicily. European Review for Medical and Pharmacological Sciences 201418 352-358.

120 Chiodini I, Torlontano M, Scillitani A, Arosio M, Bacci S, Di Lembo S, Epaminonda P, Augello G, Enrini R, Ambrosi B et al. Association of subclinical hypercortisolism with type 2 diabetes mellitus: a case-control study in hospitalized patients. European Journal of Endocrinology 2005153 837-844. (doi:10.1530/ eje.1.02045)

121 Terzolo M, Reimondo G, Chiodini I, Castello R, Giordano R, Ciccarelli E, Limone P, Crivellaro C, Martinelli I, Montini M et al. Screening of Cushing's syndrome in outpatients with type 2 diabetes: results of a prospective multicentric study in Italy. Journal of Clinical Endocrinology and Metabolism 201297 3467-3475. (doi:10.1210/jc.2012-1323)

122 Martins LC, Conceicao FL, Muxfeldt ES \& Salles GF. Prevalence and associated factors of subclinical hypercortisolism in patients with resistant hypertension. Journal of Hypertension 201230 967-973. (doi:10.1097/HJH.0b013e3283521484)

123 Omura M, Saito J, Yamaguchi K, Kakuta Y \& Nishikawa T. Prospective study on the prevalence of secondary hypertension among hypertensive patients visiting a general outpatient clinic in Japan. Hypertension Research 200427 193-202. (doi:10.1291/ hypres.27.193)

124 Mullan K, Black N, Thiraviaraj A, Bell PM, Burgess C, Hunter SJ McCance DR, Leslie H, Sheridan B \& Atkinson AB. Is there value in routine screening for Cushing's syndrome in patients with diabetes? Journal of Clinical Endocrinology and Metabolism 201095 2262-2265. (doi:10.1210/jc.2009-2453)

125 Shimon I. Screening for Cushing's syndrome: is it worthwhile? Pituitary 201518 201-205. (doi:10.1007/s11102-015-0634-9)

126 Kok C \& Sambrook PN. Secondary osteoporosis in patients with an osteoporotic fracture. Best Practice and Research in Clinical Rheumatology 200923 769-779. (doi:10.1016/j.berh.2009.09.006)

127 Hofbauer LC, Hamann C \& Ebeling PR. Approach to the patient with secondary osteoporosis. European Journal of Endocrinology 2010162 1009-1020. (doi:10.1530/eje-10-0015)

128 Warriner AH \& Saag KG. Glucocorticoid-related bone changes from endogenous or exogenous glucocorticoids. Current Opinion in Endocrinology, Diabetes and Obesity 201320 510-516. (doi:10.1097/01.med.0000436249.84273.7b)

129 Morelli V, Reimondo G, Giordano R, Della Casa S, Policola C, Palmieri S, Salcuni AS, Dolci A, Mendola M, Arosio M et al. Long- 
term follow-up in adrenal incidentalomas: an Italian multicenter study. Journal of Clinical Endocrinology and Metabolism 201499 827-834. (doi:10.1210/jc.2013-3527)

130 Shi L, Sánchez-Guijo A, Hartmann MF, Schönau E, Esche J, Wudy SA $\&$ Remer T. Higher glucocorticoid secretion in the physiological range is associated with lower bone strength at the proximal radius in healthy children: importance of protein intake adjustment. Journal of Bone and Mineral Research 201530 240-248. (doi:10.1002/jbmr.2347)

131 Osella G, Ventura M, Ardito A, Allasino B, Termine A, Saba L, Vitetta R, Terzolo M \& Alberto A. Cortisol secretion, bone health, and bone loss: a cross-sectional and prospective study in normal nonosteoporotic women in the early postmenopausal period. European Journal of Endocrinology 2012166 855-860. (doi:10.1530/ EJE-11-0957)

132 Ramli ES, Suhaimi F, Asri SF, Ahmad F \& Soelaiman IN. Glycyrrhizic acid (GCA) as 11 $\beta$-hydroxysteroid dehydrogenase inhibitor exerts protective effect against glucocorticoid-induced osteoporosis. Journal of Bone and Mineral Metabolism 201331 262-273. (doi:10.1007/ s00774-012-0413-x)

Received 30 March 2016

Revised version received 4 July 2016

Accepted 13 July 2016 